\title{
Fusarium Wilt of Bananas: A Review of Agro-Environmental Factors in the Venezuelan Production System Affecting Its Development
}

\author{
Barlin O. Olivares ${ }^{1, *}$, Juan C. Rey ${ }^{2} \mathbb{D}$, Deyanira Lobo ${ }^{2} \mathbb{D}$, Juan A. Navas-Cortés ${ }^{3} \mathbb{D}$, José A. Gómez ${ }^{3} \mathbb{D}$ \\ and Blanca B. Landa $3, *$ (D) \\ 1 Programa de Doctorado en Ingeniería Agraria, Alimentaria, Forestal y del Desarrollo Rural Sostenible, \\ Campus Rabanales, Universidad de Córdoba, 14071 Cordoba, Spain \\ 2 Facultad de Agronomía, Universidad Central de Venezuela, Maracay 02105, Venezuela; \\ jcrey67@gmail.com (J.C.R.); lobo.deyanira@gmail.com (D.L.) \\ 3 Instituto de Agricultura Sostenible, Consejo Superior de Investigaciones Científicas, 14004 Cordoba, Spain; \\ j.navas@csic.es (J.A.N.-C.); joseagomez@ias.csic.es (J.A.G.) \\ * Correspondence: barlinolivares@gmail.com (B.O.O.); blanca.landa@csic.es (B.B.L.)
}

check for

updates

Citation: Olivares, B.O.; Rey, J.C.; Lobo, D.; Navas-Cortés, J.A.; Gómez,

J.A.; Landa, B.B. Fusarium Wilt of Bananas: A Review of Agro-

Environmental Factors in the Venezuelan Production System Affecting Its Development. Agronomy 2021, 11, 986. https://doi.org/ 10.3390/agronomy11050986

Academic Editor: Malgorzata Jedryczka

Received: 23 April 2021

Accepted: 13 May 2021

Published: 15 May 2021

Publisher's Note: MDPI stays neutral with regard to jurisdictional claims in published maps and institutional affiliations.

Copyright: (C) 2021 by the authors Licensee MDPI, Basel, Switzerland. This article is an open access article distributed under the terms and conditions of the Creative Commons Attribution (CC BY) license (https:// creativecommons.org/licenses/by/ $4.0 /)$

\begin{abstract}
Bananas and plantains (Musa spp.) are among the main staple of millions of people in the world. Among the main Musaceae diseases that may limit its productivity, Fusarium wilt (FW), caused by Fusarium oxysporum f. sp. cubense (Foc), has been threatening the banana industry for many years, with devastating effects on the economy of many tropical countries, becoming the leading cause of changes in the land use on severely affected areas. In this article, an updated, reflective and practical review of the current state of knowledge concerning the main agro-environmental factors that may affect disease progression and dissemination of this dangerous pathogen has been carried out, focusing on the Venezuelan Musaceae production systems. Environmental variables together with soil management and sustainable cultural practices are important factors affecting FW incidence and severity, excluding that the widespread dissemination of Foc, especially of its highly virulent tropical race 4 (TR4), is mainly caused by human activities. Additionally, risk analysis and climatic suitability maps for Foc TR4 in Venezuela have been developed. Although currently there are no effective management solutions available for FW control, this perspective provides an overview on the influence that environmental and agricultural variables would have on FW incidence and severity, giving some insight into management factors that can contribute to reducing its detrimental effects on banana production and how climate change may affect its development.
\end{abstract}

Keywords: banana diseases; climatic suitability; Fusarium oxysporum f. sp. cubense; pathogenic races; risk factors

\section{Introduction}

According to the FAO [1], the banana (Musa spp.) is a source of staple food for a large part of the world's population. Its annual production during the 2000-2015 period grew at a rate of $3.7 \%$, reaching a record of 117.9 million tons in 2015, compared to 68.2 million tons in 2000. Due to the rapid growth of this crop, world banana exports, excluding plantain, reached the highest production of 20.2 million tons during 2019, with strong growth of the supply of two main producers (Ecuador and Philippines) being responsible mainly for the increased exports. World banana export volumes reached approximately 18.9 million tons during 2019. Preliminary estimates indicate a $4 \%$ growth in the largest net importer, the European Union, and a contraction of $1 \%$ in the United States.

In the Venezuelan territory, there were 82,000 productive hectares of banana 'Cavendish' (Musa AAA) and 'Hartón' (Musa AAB) in 2017, with a production of 424,649 tons destined for the local and export market, whose average yield was 13.91 tons/ha [1]. The production of Musaceae in Venezuela is concentrated in four large areas: the western (Zulia, Mérida, 
Táchira and Trujillo States), the southwestern (Barinas, Portuguesa and Apure States), the central (Aragua, Carabobo, Yaracuy, Vargas and Miranda States) and, to a limited extent, in the eastern (Sucre, Delta Amacuro State) zones of the country [2].

Banana production worldwide can be curtailed by several fungal diseases including aerial (e.g., Anthracnose and Fungal Scald, Botryodiplodia Finger Rot, Brown Spot and Diamond Spot, Cigar-End Rot, Cladosporium Speckle, Cordana Leaf Spot (Leaf Blotch), Pitting Disease, Sigatoka Leaf Diseases and Black Tip), soil-borne (e.g., Fusarium Wilt or Panama Disease, root rot) and postharvest (e.g., Crown Mold, Crown Rot and Pedicel Rot) diseases [3]. Among them, Fusarium wilt (FW) of bananas (FWB) caused by Fusarium oxysporum f. sp. cubense (E.F. Sm.) W.C. Snyder and H.N. Hansen (Foc), is the main threat and limiting factor for different banana cultivars of economic and strategic importance all over the world [4].

In recent decades, scientific interest in the FW of bananas has increased, especially in the main banana producing countries. This disease is the main phytopathological problem of banana plantations in tropical areas. However, despite the overwhelming impact that Foc has had over the years, and although there is extensive information concerning the biology and genetic diversity of this pathogen [4], there is still limited information available on its biogeography with concerning soil and climate, and in particular, there is no precise information on the agro-environmental factors that directly or indirectly affect the epidemiology of this disease [5]. This information would be relevant to a broader and more comprehensive understanding of the phytosanitary problem that Foc represents for banana plantations. Particularly, it can provide insight into its relationship with other fundamental agronomic components, which may be useful for the management of bananas and the disease. Therefore, this article aims to present an updated, reflective and practical review of the current state of knowledge of the main agro-environmental factors that affect the development and spread of FW of bananas, focusing on Venezuelan production. With the scientific knowledge collected in this report, it will be possible to design or select sustainable management strategies to prevent or help to reduce FW incidence in banana plantations.

\section{The Causal Agent of FW of Banana and Its Geographical Distribution: The Risk Posed by Tropical Race 4 (TR4) of Foc}

Historically, Foc, the causal agent of FW of bananas, is the main threat for different banana cultivars of economic and strategic importance worldwide. Detailed analysis and description of FW of bananas or its causal agent $(F O c)$ has been thoroughly reviewed in the past [6-8], and more recently [4,9-15], although most of the analysis has devoted limited attention to the interaction between FW and agro-environmental factors.

Foc is a pathogen that inhabits the soil and produces three types of asexual spores: microconidia, macroconidia and chlamydospores [16]. The chlamydospores are highly resistant double membrane propagules that allow the pathogen to remain viable in the soil for many years in absence of a host, making it not possible to replant susceptible cultivars in the same soil once infested [17].

Three races of Foc (Race 1 (R1), Race 2 (R2) and Race 4 (R4)) and several Vegetative Compatibility Groups (VCG) within each race differing in virulence have been described in the populations of this pathogen $[14,18,19]$. Foc R1 is responsible for the epidemic in 'Gros Michel' and 'Manzano' clones, in addition to 'Pome' (AAB), 'Pisang Awak' (ABB), and 'Maqueño' (AAB). Foc R2 especially attacks bananas belonging to the subgroup 'Bluggoe' or 'Topocho' (ABB) [19]. Foc R4 is the most dangerous of all races because it attacks all these groups of banana plants, including the Cavendish clone [6,11].

The Foc originates from Southeast Asia and has coevolved in conjunction with the Musaceae in its center of origin, being reported in all the banana producing regions of the world (Figure 1), except in the south of the Pacific Islands, Somalia and riparian countries of the Mediterranean Basin [18,20]. The disease was first described by Bancroft in 1876 in Australia [9,20], and then by Ashby in 1913 in Costa Rica and Panama, where approximately 
80,000 ha of the Gros Michel cultivar (AAA) were destroyed in Latin America by Foc R1 between 1890 and 1960 [9].

Foc R4 is the most virulent of the three races and is subdivided into Tropical (TR4) and subtropical (SR4) races. Foc SR4 attacks banana cultivars of the 'Cavendish' group in subtropical regions such as Taiwan, the Canary Islands (Spain), South Africa and Australia. Studies on the recognition of TR4 as a different Foc pathotype have been proposed by Buddenhagen [21] and show that TR4 isolates are highly virulent even under environmental conditions non-conducive for disease development (e.g., cold climates) [19,22]. Foc TR4 affects banana cultivars of the 'Cavendish' group in Australia and the tropical regions of Southeast Asia including China, Indonesia, Malaysia and the Philippines (Figure 1) $[8,23,24]$. Indeed, very recently this Foc TR4 was found to be genetically distant from the other races and has been described as Fusarium odoratissimum [20].

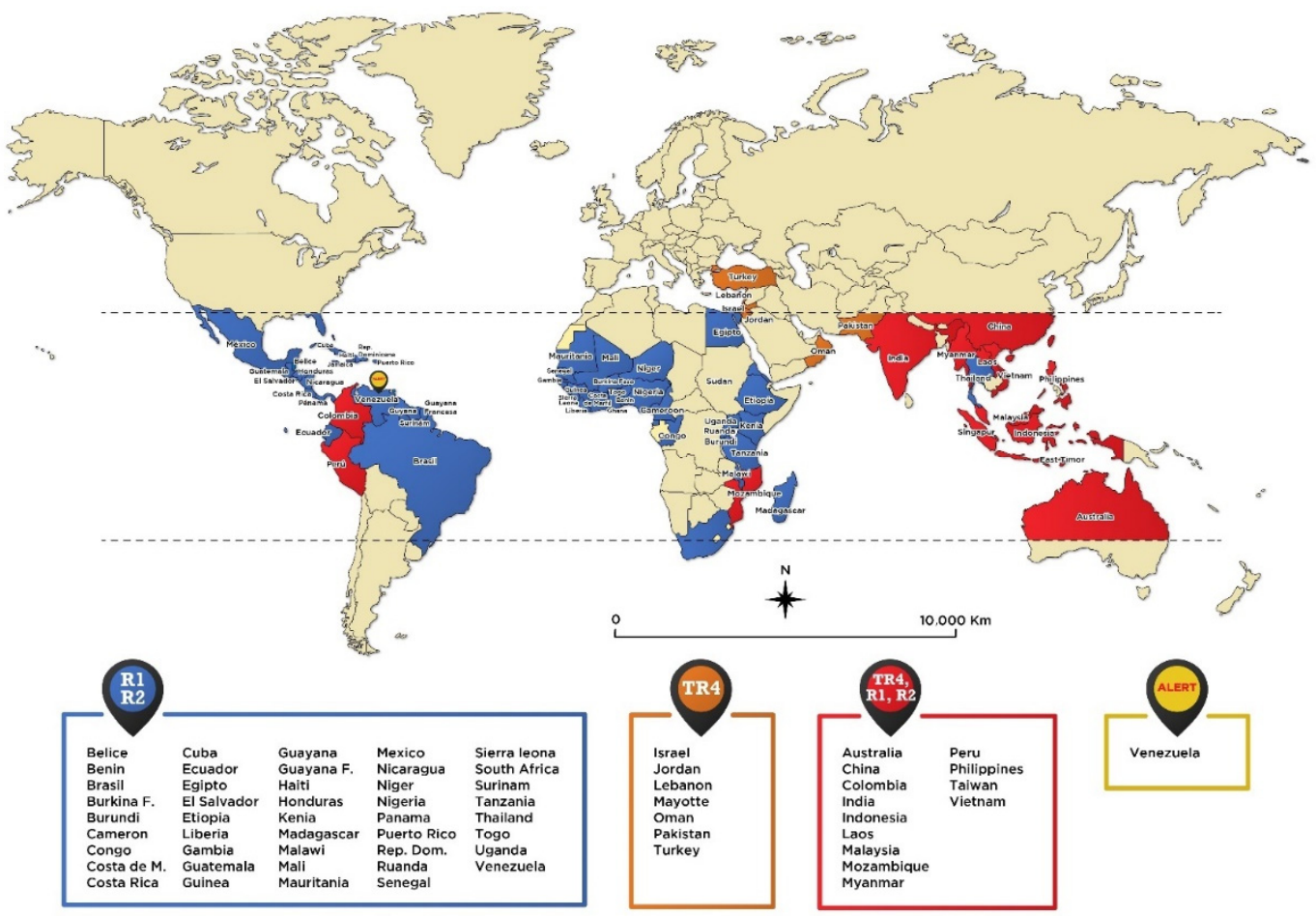

Figure 1. Geographical distribution of Fusarium oxysporum f. sp. cubense (Foc) races. Source: Adapted from CABI/EPPO [25], EPPO [26] and PROMUSA [27].

The fact that Foc R4 is destroying the cv. Cavendish in the tropics may cause unexpected harmful effects on production and exports in Southeast Asia and the 'Cavendish' market in the Western Hemisphere [4,20]. Thus, this situation threatens the production of small and medium banana farmers in Latin America and West Africa. In August 2019, the state of the national phytosanitary emergency was officially reported in Colombia due to the detection of Foc TR4 in 'Cavendish' banana crops in the municipalities of Dibulla and Riohacha (Guajira) [28]. In April 2021, the National Agrarian Health Service of Peru confirmed the finding of a banana orchard infected by Foc TR4 in the Piura Department. This situation represents a high risk for Colombia and Peru but also for other producing countries in the region.

In Venezuela, there is a latent concern of the spread of the TR4 from Colombia to bordering areas. So far, only the Foc R1 and R2 are present in Venezuelan producing areas [14]. Consequently, minimizing the spread of Foc TR4 will depend on strict compliance with established quarantine measures, such as preventing the transfer of banana shoots and rhizomes from affected to disease-free areas. In this way, the prevention strategy would protect production in the western part of Venezuela. 


\section{Disease Cycle of Fusarium Wilt of Bananas}

Foc infects the plant through the root system reaching the xylem vessels, where it grows and multiplies, occluding them and limiting the nutrient and water absorption by the plant. The pathogen can also grow saprophytically in surrounding tissues as diseased plants die, forming chlamydospores that remain in the soil (Figure 2, phase 1). The chlamydospores are stimulated by plant root exudates, which subsequently germinate and infect the roots of nearby healthy plants (Figure 2, phase 2) [13]. After germination, and root infection, more mycelium and chlamydospores are produced, infecting secondary or tertiary banana roots (Figure 2, phase 3).

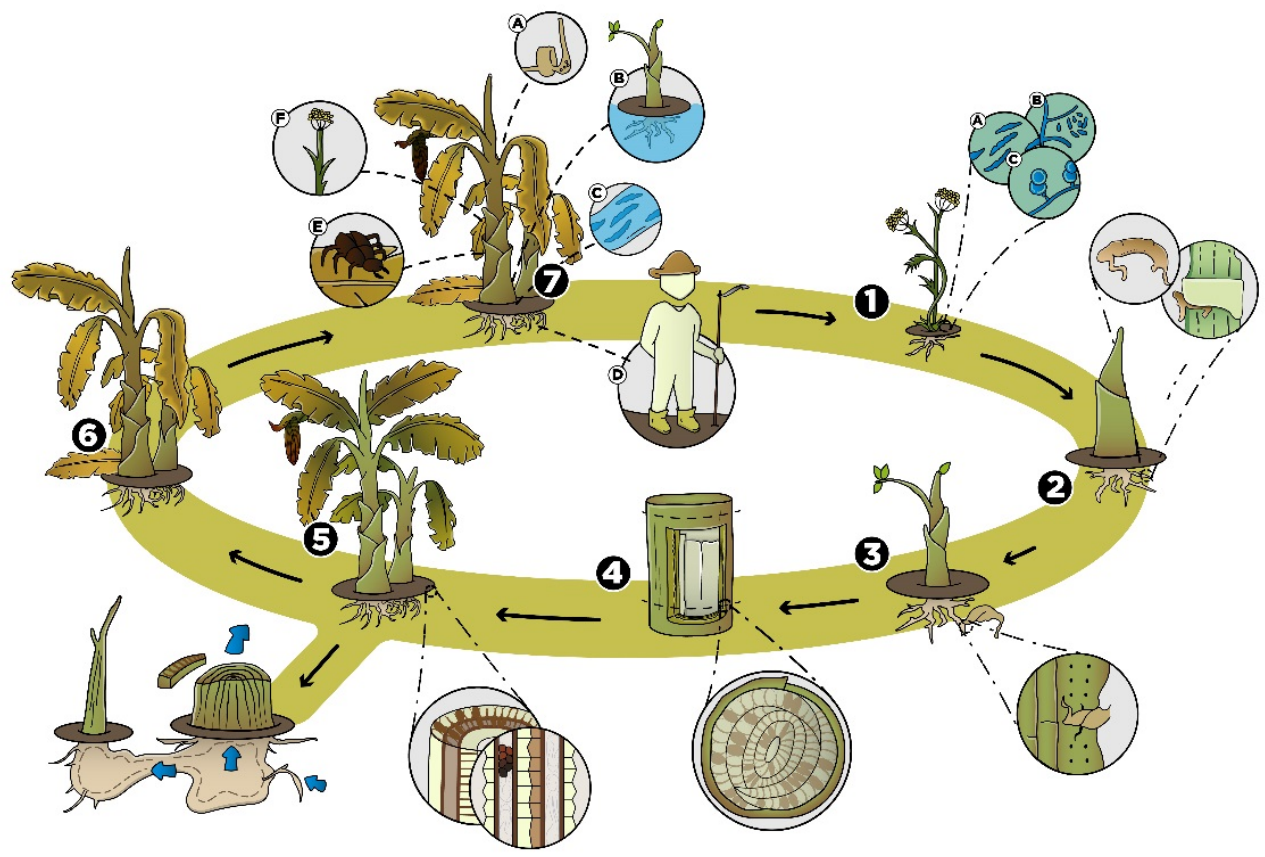

Figure 2. Schematic representation of the disease cycle of Fusarium wilt of banana, Ghag et al. [13] and Dita [14]. (1) Foc Spores (micro and macro conidia and chlamydospores); (2) germination of the chlamydospores; (3) colonization of the roots; (4) corm infestation; (5) development of wilt symptoms; (6) complete wilting of the mother plant; (7) pathogen dissemination: a. planting material; b. drainage water and runoff; c. irrigation water; $d$. workers; e. the weevil; f. weeds.

In susceptible plants, the fungus is not blocked by the host's defense mechanisms and the infection becomes systemic through the vascular system of the corm, the pseudo-stem, and the stem (Figure 2, phase 4). In resistant cultivars, the fungus is blocked by host responses and vascular occlusion of the infected xylem vessels, making the pathogen not able to continue infecting the corm [8,13]. In general, young plants have been described as most susceptible [6,7], due to the presence of younger roots that are more susceptible to Foc infection [15].

As Foc blocks the water flux in xylem vessels, the leaves turn yellow and wilt, making this effect more pronounced as leave age increases. Distinctive symptoms appear within the pseudo-stem, whose main characteristics are brown, red, or yellow ring-shaped lines. In the corm, brown stripes or specks appear (Figure 2, phase 5 and 6). Infected plants generally do not produce fruit, or the size of them is reduced [8] (Figure 3).

Foc being a soil-borne pathogen, movement of infested soil can disperse soil particles infested by fungal structures (e.g., spores and mycelium). In addition, irrigation water, the weevil Cosmopolites sordidus and other secondary hosts such as ornamental plants and weeds can contribute to the spread of the pathogen [4,29]. The movement of plants as planting material also plays a significant role in pathogen dissemination (Figure 2, phase 7) [4]. A summary of the main Foc dispersal means is discussed below (see Section 4.6. Hosts and Dispersion). 


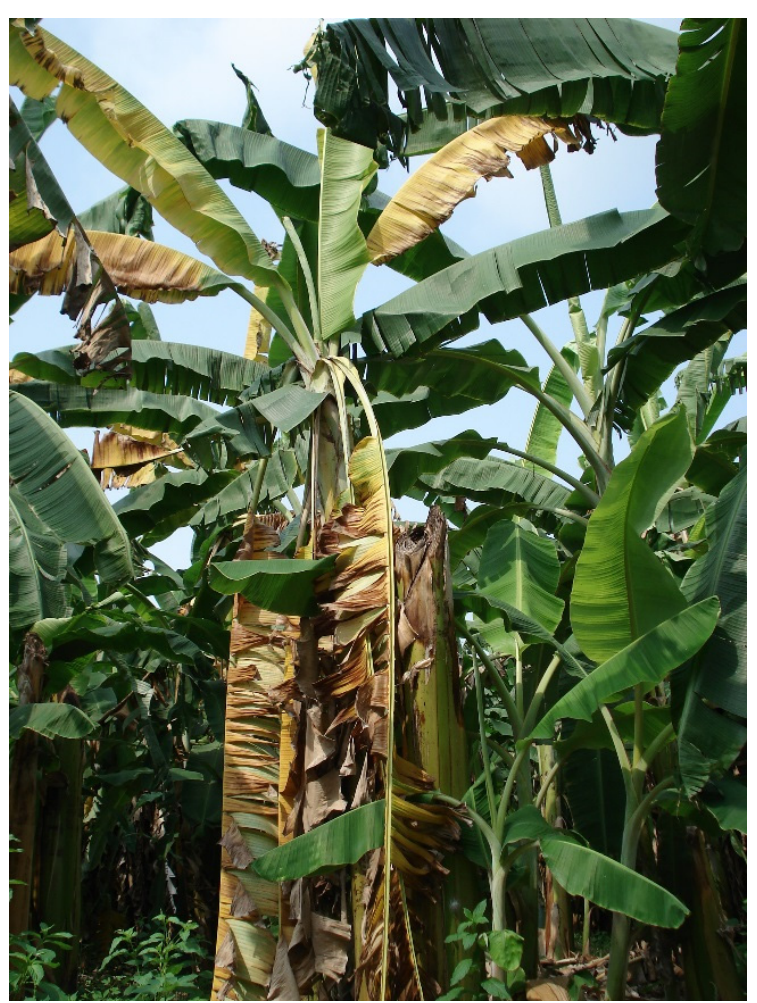

(a)

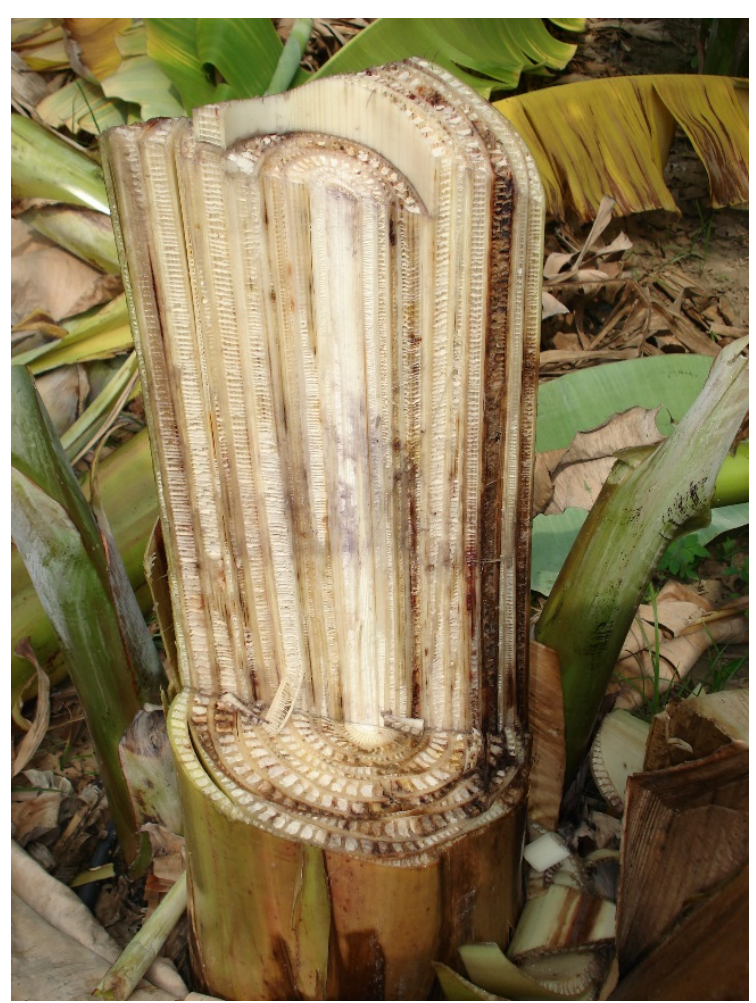

(b)

Figure 3. Fusarium oxysporum f. sp. cubense symptoms in plants of banana clone 'Manzano' growing at 'El Diamante' Farm, El Cenizo Irrigation System, Sabana Mendoza, Trujillo State of Venezuela. (a) The first external symptoms of Fusarium Wilt are chlorosis and the death of the oldest leaves, which usually bend and collapse against the pseudo-stem. (b) Internal brown to red brick discoloration of the vascular system. [Pictures by Gustavo Martínez] (Trujillo-Venezuela, 2009).

\section{Factors That Affects the Development of Fusarium Wilt Epidemics in Banana Crops}

Several abiotic and biotic factors of physical, chemical, microbial, climatic, or even sociocultural nature, have been shown to have an important role in the interactions among the banana crop, the pathogen and the soil environment. As a result of those complex and site-specific interactions, FW of banana may develop or not, leading to detrimental levels for banana production. Table 1 shows a summary of the agro-environmental variables that influence the incidence of $F o c$ and the suppressive or conducive nature of soils to Fusarium wilt of bananas.

\subsection{Environmental Conditions: Current and Future Climate Change Scenarios}

In general, banana growth is not significantly limited by solar radiation or temperature, precipitation being the most important climatic factor for rain-fed plantations [30]. However, these factors can directly influence the occurrence of certain tropical diseases such as Black Sigatoka (Mycosphaerella fijiensis Morelet), Yellow Sigatoka (Mycosphaerella musicola Leach et Mulder) and False Panama disorder (of unknown etiology) [31]. However, in the case of banana-producing farms located in the extratropical zone, the temperature would represent a limiting factor for the adequate growth of the plants [32]. In the literature it is reported that banana cultivation is characteristic of tropical lowlands, in latitudes below $10^{\circ}$, altitudes around $100 \mathrm{~m}$ above sea level, minimum average temperature values of $19^{\circ} \mathrm{C}$ and total rainfall exceeding $100 \mathrm{~mm} / \mathrm{month}$ [33].

According to Nelson [16], the optimum temperature for in vitro growth of F. oxysporum isolates is between 25 to $28^{\circ} \mathrm{C}$, being restricted when the temperature exceeds $33^{\circ} \mathrm{C}$ or is below $17^{\circ} \mathrm{C}$. Similarly, Pérez et al. [34] determined the effect of temperature on the growth of Foc isolates belonging to R1 and R2 races. They found that isolates of both races develop optimally in a wide range of temperatures between 23 to $29^{\circ} \mathrm{C}$, to rapidly decrease their 
growth outside this range. In a different study, Groenewald et al. [35] found differences in growth rate in vitro of Foc isolates at different incubation temperatures, identifying an optimum temperature of $25^{\circ} \mathrm{C}$ for almost all isolates, while growth was limited at 10 and $35^{\circ} \mathrm{C}$ and no growth was observed at 5 and $40^{\circ} \mathrm{C}$. Under field conditions, Brake et al. [36] showed that temperature mainly affects plant growth rather than directly affects the virulence of the pathogen. However, under temperature values around its optimal values for growth, higher severity of the disease would be expected since the growth and reproduction of the fungus would be favored by these environmental conditions. Moreover, high temperature values would also favor water stress in the plants, enhancing the severity of Foc symptoms. Ploetz [37] showed that temperature had an important effect on the development of FW disease. In this context, the level of susceptibility/resistance to Foc R1 in certain banana cultivars, such as 'Lacatan' or 'Gros Michel', would largely depend on temperature. That is, in certain banana cultivars the level of disease would increase under a temperature range optimum for disease development compared to that developed when suboptimal temperatures prevail.

Current research suggests that one of the main consequences of climate change would be the increase of temperatures and the alteration of rainfall patterns that could modify the incidence of pests, diseases and consequently impact the productivity of crops. Although the information on the occurrence records available for the different formae speciales of F. oxysporum for Foc in banana crops is limited, some studies have modeled the future distribution of other formae speciales of F. oxysporum estimating that at the species level, this fungus would find suitable areas for growth in North Africa, Middle Eastern and European countries for the years 2050 and 2100 [5]. In a similar analysis, Pérez-Vicente and Porras [38] have estimated for different climate change scenarios in Cuba, leading to a reduction in the geographic extent of the Foc pathogen, although FW would increase its severity when present. Additionally, in conditions of extreme events of heavy rains that could cause flooding, whose incidence might increase in some areas as a result of climate change, Foc could severely affect areas with susceptible cultivars such as the Burro (Bluggoe, ABB) types. These authors $[5,38]$ also indicate that the reported temperature range for the pathogen exceeds the temperature range prevalent in areas where the disease occurs in Cuba, and the expected increase in temperature in the future would render these areas not suitable for FW development.

It is important to note that in rainfed cultivation, banana is very sensitive to water stress, particularly in areas without optimum soil and climate conditions, whose productivity can be reduced by up to $50 \%[39,40]$. Waterlogging of the soil can produce symptoms of leaf yellowing and necrosis at the tips of the roots in banana plants, which can be confused with symptoms of FW. According to Lahav and Israeli [41], conditions of excessive moisture in the soil or waterlogging would predispose the plant to infection by the pathogen. The impact of oxygen deficiency on the interaction with Foc was evaluated by Aguilar et al. [42] based on changes in the activities of enzymes involved in phenol metabolism (phenylalanine ammonia lyase, PAL and peroxidase, PER) in banana cultivars differing in their reaction to Foc. Infected plants were subjected to hypoxia-induced changes in PER activity, which correlated with their resistance to FW. However, a breakdown of resistance to Foc of cv. Williams (a Cavendish cultivar) occurred when the soil was waterlogged. On the contrary, it has also been documented that flooding longer than 18 months destroys Foc's reproductive structures [37]. On the contrary, it is well established that Fusarium spp. can survive in the soil for long periods when unfavorable drought conditions occur [43]. However, in arid or semi-arid conditions, with rainfall below $500 \mathrm{~mm} /$ year, it has been shown that soil moisture levels and temperature conditions can be unfavorable for Foc growth and development [40]. However, although mycelium and conidia survive for a short time in very dry soils, this stress situation represents a starting point for the development of Foc chlamydospores that can remain dormant for approximately 20 to 30 years [36]. 


\subsection{Land and Soil Physical Properties}

Bosman [32] studied the relationship between the slope in the field and the incidence of Foc in banana plantations in tropical soils of Costa Rica, finding that steep slopes have more erosion and nutrient losses than gentle slopes, where sediments often accumulate. Erosion also contributes to the spread of Foc inoculum that is transported with the sediments and runoff. In addition, steep and slope location influences the water availability in the soil and the amount of runoff water, and the movement of Foc inoculum close to the root system [44].

Soil structure, often expressed as the degree of stability of aggregates, exerts important influences on the edaphic conditions and the environment and results from the rearrangement, flocculation and cementation of soil particles. It is mediated by soil organic carbon (SOC), biota, ionic bridging, clay and carbonates [45]. Li et al. [46] analyzed two typical banana-growing soils (ultisol and inceptisol), which were either suppressive or conducive to the FW of banana from Hainan, China. They found that the suppressive soils had significantly more $>2$ and $<0.053 \mathrm{~mm}$ aggregates, had a comparatively even size distribution of aggregates within the range of $0-0.25 \mathrm{~mm}$, and a higher total carbon, total nitrogen and soil enzyme activity in the aggregates.

In the Canary Islands, Spain, Domínguez et al. [47] found that soils suppressive to Foc had high EC, higher levels of clay and soluble Na. In the same region, on volcanic soils, Domínguez et al. [48] found a clear separation between areas with and without FW, finding that the soluble $\mathrm{K} / \mathrm{Na}$ ratio was always greater in affected areas, which is correlated with higher amounts of clay-sized particles and the increase of water-stable aggregate mass in these diseased areas. Moreover, the low potential buffering capacity for $\mathrm{K}$ observed in diseased areas suggests that massive $\mathrm{K}$ fertilizations might exert a negative effect on the disease development in banana plants. In Brazil, Deltour et al. [49] showed that soils with a higher level of suppressiveness to Foc R1 are characterized by higher clay content and higher $\mathrm{pH}$, which suggests that soils with heavy texture could be less prone to the development of FW than sandy soils with lower $\mathrm{pH}$.

\subsection{Soil Chemical Properties}

Multiple soil chemical properties including $\mathrm{pH}$, organic matter content and the availability of some micronutrients in the soil are related to the suppressiveness to FW of certain soils. However, this effect largely depends on the soil type and climate, which makes it not possible to generalize the effect of those soil properties on the development of FW diseases. Nevertheless, for the specific case of FW of bananas, some research works have identified some specific chemical soil properties including $\mathrm{pH}$, and organic matter, potassium, phosphorus, nitrogen and magnesium content (either by excess or deficient levels) as key factors contributing to reduce the susceptibility of banana crops to FW [50-52].

Concerning $\mathrm{pH}$, Foc can grow in vitro in a wide $\mathrm{pH}$ range (optimal, 7.5-8.5) [36,46]. Under field conditions, some works have reported that, in the banana zones of Central America, the fungus seems to have different ranges of optimal $\mathrm{pH}$ depending on the soil type. Thus, several works have presented contradictory results. For example, Chuang [53] pointed out that the germination of Foc chlamydospores in the soil was negatively correlated with a $\mathrm{pH}$ of $8-10$, which caused the pathogen to survive longer in alkaline soils ( $\mathrm{pH} 8-10)$ than in very acid ones ( $\mathrm{pH} 2-4)$ and Peng et al. [54] showed a higher incidence of FW in alkaline conditions. However, Bosman [32] recorded a high incidence of Foc in tropical banana soils with an acidic $\mathrm{pH}$ of 5.1, a condition in which the growth of the fungus in the soil was promoted [55].

Concerning soil nutrients, it has been observed in the banana plantations that certain fluctuations in the availability of specific nutrients may cause stress in banana plants and, consequently, increase their susceptibility to the attack of diseases, such as FW [56]. Within the macronutrients, potassium has been shown to have a direct and indirect influence on the incidence of FW. Soils with potassium deficiencies are directly correlated with a high incidence of the disease [57]. According to Domínguez et al. [48], the content of 
potassium in soil solution together with the presence of fine clay particles in the soil induce the suppression of FW in banana plantations in volcanic soils grown in arid and semi-arid regions, such as the Canary Islands.

In banana plantations in Costa Rica, the areas with a high incidence of Foc have a lower average phosphorus concentration $(20 \mathrm{mg} / \mathrm{L})$ than the areas with low incidence, resulting from this a nutrient that is very important not only for the health status of the plants but also for the incidence of FW [32,52]. In the Canary Islands, the study conducted by Borges [58] showed that zinc application to the soil significantly reduced the incidence and severity of FW in bananas in that area.

Concerning magnesium, a higher incidence of diseases in banana fields is related to high concentrations of this element in the soil. Therefore, in soil, a low level of magnesium might be recommended to increase plant resistance to FW. Despite the above, magnesium is usually applied at high concentrations as fertilizer to increase banana growth.

Interestingly, rather than the concentration of specific nutrients in the soil, some authors highlighted the importance of the Potassium/Magnesium ratio in the reaction of banana crops to Foc. Thus, Borges [59] reported that banana soils infected by Foc in the Canary Islands have the highest values of the Potassium/Magnesium ratio (0.67) compared to soils with healthy plants (0.48). The absolute values of potassium in these soils are commonly high due to the frequent applications of potassium salts as fertilizers. On the other hand, the absolute values of magnesium were low in soils that presented the disease. Other studies have indicated that Potassium/Magnesium ratio ranges between $0.55-0.81$ are associated with serious losses due to FW in banana plantations in the Canary Islands [56].

\subsection{Crop Management}

At the banana production unit level, agroecosystem management seems to have a major role in the incidence of FW. For example, the use or establishment of a green cover in banana plantations based on fodder peanut (Arachis pintoi), grass carpet (Axonopus affinis) and indigenous native grass (Paspalum conjugatum) have been shown to have a positive impact on reducing the incidence of FW $[60,61]$. In line with this observation, it is commonly observed that a high percentage of bare soil (30.1\%), which is related to a higher incidence of FW in the banana fields of Central America [32]. Experiences in this region and in Australia suggest that the presence of bare soil should be avoided and replaced by a green or brown cover [61].

Practices like biological disinfestation of the soil based on the incorporation of the cover crop or organic amendments (rice straw) of easy decomposition, flooding with irrigation and covering with a plastic film, leads to anaerobic conditions, which helps to control the attack of pathogens including Foc [62].

Intercropping and crop rotation are old practices that are used for disease control [39]. For the FW of banana, the rotation with Chinese chives (Allium tuberosum) is a cultural practice capable of reducing the incidence of Foc disease in China, significantly inhibiting the growth and causing the death of Foc spores $[49,63]$.

Another aspect to consider is plant density. According to Bosman [32], if the plantation has a higher plant density ( $<3 \mathrm{~m}$ of plant spacing), the chances of the plants becoming infected is higher. A smaller distance between banana plants generates negative impacts on their health through competition, and increases the chances of Foc infection. However, the opposite effect may occur due to lower microbial activity, since the root activity is reduced and movement of water in the soil limited, resulting in a condition of less fertile soils and, therefore, more susceptibility to Foc attack [14].

Finally, there are studies indicating that the addition of chicken manure increases the inoculum of Foc in soil and the incidence of FW, despite being an agricultural practice that improves the soil fertility in banana plantations infected by Foc [51,64]. 


\subsection{Soil Biota}

The proportional size of abundance of microbial populations in soils appears to have a large influence of $\mathrm{FW}$ on bananas $[54,65,66]$. On this premise, microbial soil populations are essential to suppress Foc in this environment, while on the other hand, the physical and chemical properties of the soil affect the growth and development of the microbial population in the plant rhizosphere.

Bacterial and fungal communities were mainly determined by the organic matter content in banana soils in China [66]. These bacterial and fungal communities were significantly altered after long-term banana monoculture, indicating that the increase in fungal richness showed a significant correlation with the high incidence of FW disease. In this regard, Deng et al. [67] showed that the metabolic characteristics of the microbial communities present in a banana plantation in China, were significantly different when comparing healthy and diseased plants on the same banana plot.

Nowadays, the use of next-generation sequencing techniques is facilitating the study and the understanding of the plant-associated microbial communities and their shifts under varying conditions. Furthermore, the plant associated microorganisms or microbiome is recognized as a key factor behind the health of the plants [68]. Although there is still a lack of knowledge concerning the relationships between the microbiome profiles of the banana plant and the rhizosphere environment, some recent works are providing insights on the effects of banana-associated microbiome and the development of FW. Thus, some studies [68-70] found a determining beneficial role of Gammaproteobacteria present in banana soils in Central America, concluding that some members of this bacterial class were associated with the lack of successful infection of banana plants by Foc in soils infected by this pathogen. Additionally, Köberl et al. [70] found an increase in the Pseudomonas and Stenotrophomonas populations of healthy banana plants, whereas FW diseased plants showed an increase in Enterobacteriaceae. More recent studies have found that the Acidobacteria phylum was significantly elevated, but Bacteroidetes was significantly reduced in banana soils suppressive to FW. Additionally, certain bacteria belonging to the genera Gp4, Gp5, Chthonomonas, Pseudomonas and Tumebacillus were specifically enriched in suppressive soils, whereas Gp2 was reduced [71]. However, it is important to point out that the exact mechanisms responsible for FW microbial suppression are probably due to complex microbial communities more than to specific bacterial genera.

The application of biological control agents (BCAs) not only effectively controls soilborne pathogens such as Foc, but also significantly promotes plant growth and increases plant biomass. For the specific case of FW of bananas, several studies have dealt with the application of BCAs at the field-testing stage, with some of them showing high effectiveness (e.g., Pseudomonas spp. Trichoderma spp., Bacillus spp., non-pathogenic Fusarium strains and arbuscular mycorrhizal fungi) [15]. The use of BCAs for controlling FW of bananas is out of the scope of this article that rather focuses on the effect of indigenous soil biota development of FW of bananas; however, for those interested in this subject, Bubici et al. [15] has recently provided a comprehensive detailed and updated revision on this topic. Overall, under field conditions, the FW of banana has been controlled by up to $79 \%$ by using Pseudomonas spp. strains, and up to 70\% by several endophytes and Trichoderma spp. strains. Lower biocontrol efficacy (42-55\%) has been obtained with arbuscular mycorrhizal fungi, Bacillus spp. and non-pathogenic Fusarium strains [15].

Other soil biotas, apart from microorganisms, may have a strong influence on the suppressiveness to FW of banana of certain soils. Thus, modifications in the microbiological properties of the soil caused by the activity of meso-and macro-organisms, such as nematodes, beneficial arthropods and earthworms, have been identified as relevant factors in the incidence of FW in monoculture banana systems [66]. FW of bananas can be exacerbated by the presence of certain nematode species (e.g., Radopholus similis), due to root lesions that weaken the plant and facilitate the penetration of the pathogen through the injuries caused by nematode feeding $[66,72]$. In the banana agroecosystems, nematodes are one of the main causes of production losses. R. similis, Helicotylenchus sp., Pratylenchus coffeae, Meloidogyne 
sp. and Rotylenchulus reniformis are some of the plant-parasitic nematode species frequently associated with crop losses in banana crops [73,74].

According to Duyck et al. [75] and Zhong et al. [76] banana soils with a high inoculum of Foc or FW incidence show a reduced diversity of total nematodes. Thus, under such conditions, the populations of bacterivores (mainly in Rhabditidae, Pangrolaimidae and Cephalobidae families), some plant parasites (mainly within Meloidogynidae, Hoplolaimidae, Pratylenchidae and Rotylenchulidae families) and omnivores or predators (mainly in Qudsianematidae family) decreased in contrast to other groups of nematodes present in non-infested-healthy soils.

Table 1. Summary of the agro-environmental variables that influence the incidence of Fusarium oxysporum $\mathrm{f}$. sp. cubense (Foc) and the suppressive or conducive nature of the soils to Fusarium Wilt (FW) of bananas.

\begin{tabular}{|c|c|c|}
\hline Variable & Description & Source \\
\hline \multicolumn{3}{|l|}{ Climate } \\
\hline \multirow{2}{*}{ Temperature } & Favorable temperature range from 23 to $29^{\circ} \mathrm{C}$, with optimum at $25^{\circ} \mathrm{C}$; & [35] \\
\hline & Limited growth at 10 to $35^{\circ} \mathrm{C}$ and no growth $\leq 5$ or $\geq 40^{\circ} \mathrm{C}$ & [34] \\
\hline \multirow{2}{*}{ Precipitation } & Water deficit: oxygen deficiency in the radical system favors Foc infection & [42] \\
\hline & Water Excess: poorly drained soils with heavy textures favor FW & [41] \\
\hline \multicolumn{3}{|l|}{ Soil physical characteristics } \\
\hline Slope & Convex curvature slope favors FW & [32] \\
\hline \multirow{2}{*}{ Distribution of the size of aggregates } & Conducive soils: $<0.053 \mathrm{~mm}$ & [46] \\
\hline & Suppressive soils: $>2.0 \mathrm{~mm}$ & [45] \\
\hline Texture & $\begin{array}{l}\text { Suppressive soils: higher clay content (high } \mathrm{pH}) \\
\text { Conducive soils: sandy texture (low } \mathrm{pH})\end{array}$ & {$[49]$} \\
\hline \multicolumn{3}{|l|}{ Soil chemical characteristics } \\
\hline $\mathrm{pH}$ & Optimal in vitro growth of Foc: $7.5-8.5$ & [36] \\
\hline Acidity & $\begin{array}{l}\mathrm{pH} \text { of } 5.1 \text { increases the availability of toxic aluminum and favors the growth } \\
\text { of } F o c\end{array}$ & {$[55]$} \\
\hline Potassium & Conducive soils: potassium deficiencies correlate with high FW incidence & [57] \\
\hline Phosphorus & Conducive soils: concentration $<20 \mathrm{mg} / \mathrm{L}$ & {$[32]$} \\
\hline Zinc & $\begin{array}{l}\text { Suppressive soils: the application of zinc in the soil significantly reduces } \\
\text { FW incidence }\end{array}$ & [58] \\
\hline Magnesium & Conducive soils: $7.9-10.6 \mathrm{cmol} / \mathrm{kg}$ & [56] \\
\hline Ratio $\mathrm{K} / \mathrm{Mg}$ & $\begin{array}{l}\text { Conducive soils: }>0.67 \\
\text { Suppressive soils: } \leq 0.48\end{array}$ & [59] \\
\hline
\end{tabular}

Soil biological properties

Bacteria

Suppressive soils: higher levels of Acidobacteria phylum, Gp4, Gp5, Chthonomonas, Pseudomonas and Tumebacillus genera [71]

Suppressive soils: increase in Pseudomonas and Stenotrophomonas populations [70] Conducive soils: Increase of Enterobacteriaceae Conducive soils: high presence of bacterivores nematodes (Rhabditidae,

Nematodes Pangrolaimidae and Cephalobidae), plant parasitic (Meloidogynidae, Hoplolaimidae, Pratylenchidae and Rotylenchulidae), omnivores or predators (Qudsianematidae)

\section{Crop management}

Green cover

Bare soil

Distance between plants

Crop rotation

Chicken manure
Green cover of forage peanut (Arachis pintoi), carpet of grass

(Axonopus affinis) and indigenous native grass (Paspalum conjugatum) reduces the incidence of $F o c$

Conducive soils: average bare soil of $30.13 \%$

Suppressive soils: average bare soil of $11.65 \%$

Conducive soils: $<3.0 \mathrm{~m}$

Suppressive soils: $\geq 4.0 \mathrm{~m}$

The rotation with Chinese Chives (Allium tuberosum) inhibits the growth of $F o c$

Increases the inoculum of $F o c$ 


\subsection{Hosts and Dispersion}

Plant genetic resistance is generally considered the most plausible strategy and economically feasible measure to effectively manage the FW of bananas [11,12]. However, resistant cultivars might not match the demands of the market and the available resistance may be overcome by new pathogenic strains, as was the case of Cavendish and Foc TR4 [22]. Once FW is established in an area, the use of resistant varieties is the most effective, if not the only means to manage the disease. In bananas, complete resistance has only been described in the Cavendish (AAA)-Foc R1 interaction. Other interactions, such as Prata (AAB)-Foc R1 and Giant Cavendish Tissue Culture Variants (GCTCV)-Foc TR4, show intermediate resistance, i.e., those banana genotypes develop less severe symptoms than susceptible varieties when grown under similar environmental conditions and Foc inoculum levels. However, under-management practices and inoculum pressure conducive for disease development; FW and yield losses will increase gradually [14]. Currently, efforts are being made to unravel the genetic and molecular mechanisms driving resistance responses of different banana genotypes using state-of-the-art molecular approaches such as deep-RNA sequencing [77]. A description of the levels of resistance and its implications on FW of banana management is described in Dita et al. [14].

Foc is a facultative saprophytic fungus, with the ability to survive in weeds and grasses. Thus, Foc can invade roots of weeds present in banana plantations from hyphae growing from the tissues of senescent banana roots that remain in the soil for long periods [78]. This could explain the persistence of the fungus in soils without banana crops [7]. Thus, the pathogen can infect the roots of certain weeds without causing visible symptoms and can remain in these plants in the absence of a banana crop [79]. The study of Hennessy et al. [78] found that the monocotyledonous species Chloris inflata and three dicotyledonous species: Euphorbia heterophylla, Tridax procumbens and Cyanthilium cinereum, can sustain Foc inoculum in their root system (Table 2). Among the different plant species that can be hosts of Foc, it is of particular relevance to avoid or control the export of the ornamentals Canna indica, Aglaonema pictum and Hedychium coronarium, especially in areas close to FW affected fields, since these species can serve as alternative hosts for the pathogen [80]. Additionally, it is known that monocotyledons are excellent endophytic carriers of F. oxysporum [49] and could contribute to the increase or maintenance of Foc inoculum.

The systemic growth of Foc in xylem tissues of infected asymptomatic banana plants represents one of the primary ways in which the fungus can be introduced into a free pathogen growing area $[12,13]$. The influence of the anthropogenic component by the active movement of infected planting material, equipment and people between infected and not affected areas, had important repercussions in the dissemination of Foc R1 and TR4 [14]. According to Stover [81], the epidemic of Foc R1 in 'Gros Michel' was due to the absence of quarantine measures, the use of infected planting material and the establishment of new plantations using machinery and propagation material from infected fields [14]. Thus, the pathogen is dispersed by the movement of propagating material and infested agricultural tools that have contaminated soil, runoff water during rainy events, floods and irrigation [6,11]. With the rain, the spores of the pathogen, as well as the infected material, are transported to the drainage channels and through irrigation water, these spores infect new areas. 
Table 2. Main host plants (type, family and species) of Fusarium oxysporum f. sp. cubense.

\begin{tabular}{|c|c|c|c|}
\hline Type of Plant & Family & Species & Reference \\
\hline \multirow[t]{2}{*}{ Ornamental } & Heliconiaceae & $\begin{array}{c}\text { Heliconia caribea } \\
\text { Heliconia latispatha } \\
\text { Heliconia chartacea } \\
\text { Heliconia collinsiana } \\
\text { Heliconia crassa } \\
\text { Heliconia rostrata } \\
\text { Heliconia marie } \\
\text { Heliconia vellerigera }\end{array}$ & $\begin{array}{c}{[50]} \\
{[8]} \\
{[26]}\end{array}$ \\
\hline & $\begin{array}{c}\text { Cannaceae } \\
\text { Araceae } \\
\text { Zingiberaceae }\end{array}$ & $\begin{array}{c}\text { Canna indica } \\
\text { Aglaonema pictum } \\
\text { Hedychium coronarium }\end{array}$ & [80] \\
\hline Crop & Musaceae & $\begin{array}{c}\text { Musa sp. } \\
\text { Musa schizocarpa } \\
\text { Musa textiles } \\
\text { Musa acuminata } \\
\text { Musa balbisiana }\end{array}$ & $\begin{array}{c}{[50]} \\
{[19]} \\
{[11,12]} \\
{[26]}\end{array}$ \\
\hline Weeds & $\begin{array}{c}\text { Commelinaceae } \\
\text { Poaceae } \\
\text { Asteraceae } \\
\text { Euphorbiaceae }\end{array}$ & $\begin{array}{l}\text { Commelina diffusa } \\
\text { Choris inflata } \\
\text { Ixophorus unisetus } \\
\text { Tridax procumbens } \\
\text { Euphorbia heterophylla }\end{array}$ & $\begin{array}{l}{[29]} \\
{[78]}\end{array}$ \\
\hline Grass & Poaceae & $\begin{array}{l}\text { Paspalum fasciculatum } \\
\text { Panicum purpurascens }\end{array}$ & $\begin{array}{c}{[29]} \\
{[51,78]}\end{array}$ \\
\hline
\end{tabular}

\section{Risk Analysis of Fusarium oxysporum f. sp. cubense Occurrence in Banana Plantations in Venezuela}

Venezuela has a diverse ecology and it is divided into several agroecological zones (ZAE). This division in ZAEs is based on the geographic location, edaphic and climatic characteristics, agricultural potential and the predominant agricultural production systems [82]. We have established the delimitation of the main areas of Musaceae cultivation in Venezuela and the total area yield by using the Space Production Allocation Model (SPAM) 2005 [83], developed by the International Food Policy Research Institute (IFPRI), at a spatial resolution of 5 arc-minutes (approximately $10 \mathrm{~km}^{2}$ ) (Figure 4a) [84].

The designated areas with a different potential risk of Foc occurrence in the main banana producing areas in Venezuela were based on the assembly of agro-environmental factors (climate, soil type and agronomic management) (Figure 4a). Additionally, these analyses were complemented by five Musaceae experts of Red Venezolana de Musáceas (Musaven), who classified production systems with different levels of risk or susceptibility (high-, moderate- and low-risk areas), according to the characteristics established by FAO [79].

The classification was based on the prevailing characteristics of the different Musaceae production systems in Venezuela with four important steps, including risk identification (sources, communities and production systems), analysis (probability and consequences), evaluation (prioritization) and assessment (response to the risk) (Table 3). Our results defined three areas with a different potential risk of Foc occurrence in Venezuela. 

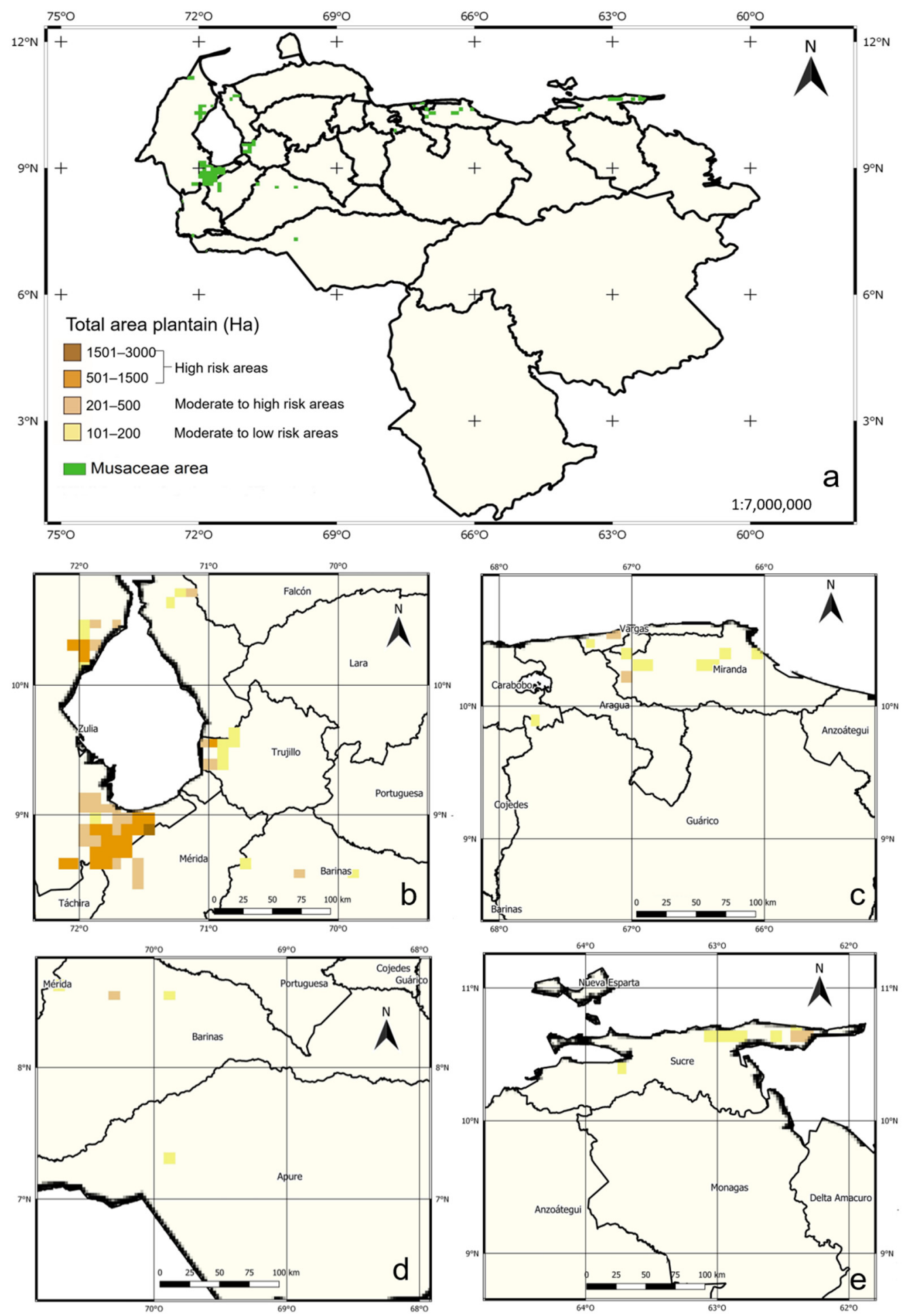

Figure 4. (a) Total area of Musaceae production in Venezuela (Source: USDA) and potential risk of Fusarium oxysporum f. sp. cubense occurrence in Venezuela in (b) the western region, (c) central region, (d) southwestern region and (e) eastern region. 
Table 3. Location and main characteristics of Musaceae producing areas in Venezuela.

\begin{tabular}{|c|c|c|c|c|}
\hline Zone & Location & Climatic Characteristics * & Edaphic Characteristics & $\begin{array}{l}\text { Predominant } \\
\text { Production Systems }\end{array}$ \\
\hline \multirow{3}{*}{ Eastern } & $\begin{array}{l}\text { Sucre State: } \\
\text { Andrés Eloy Blanco } \\
\text { and Andrés Mata } \\
\text { Municipalities }\end{array}$ & $\begin{array}{ll}\text { - } & \text { Ecoclimatic Region: } \\
\text { Subhumid premontane } \\
\text { tropics }(\mathrm{C} 1) \\
\text { - } \quad \text { Altitude: } 0-500 \mathrm{~m} \\
\text { - } & \text { AP: } 700-900 \mathrm{~mm} \\
\text { - } & \text { AAT: }>24^{\circ} \mathrm{C}\end{array}$ & $\begin{array}{l}\text { In flat areas predominate } \\
\text { soils with good drainage } \\
\text { and good natural fertility } \\
\text { In areas with high slope } \\
\text { soil quality is at risk due } \\
\text { to erosion }\end{array}$ & $\begin{array}{l}\text { Diversification of the } \\
\text { uses of Musaceae } \\
\text { (bananas and plantains) }\end{array}$ \\
\hline & $\begin{array}{l}\text { Sucre State: } \\
\text { Bermúdez Municipality }\end{array}$ & $\begin{array}{ll}\text { - } & \text { Ecoclimatic Region: } \\
& \text { semiarid }(\mathrm{G} 1) \\
\text { - } & \text { Altitude: } 0-500 \mathrm{~m} \\
\text { - } & \text { AP: } 400-500 \mathrm{~mm} \\
\text { - } & \text { AAT: }>24{ }^{\circ} \mathrm{C}\end{array}$ & $\begin{array}{l}\text { Areas of valleys and plains } \\
\text { with low slope, with saline } \\
\text { soils. Irrigation and water } \\
\text { quality are determining } \\
\text { factors for agricultural use }\end{array}$ & $\begin{array}{l}\text { It is characterized by } \\
\text { rainfed subsistence and } \\
\text { semi-commercial } \\
\text { agriculture. }\end{array}$ \\
\hline & $\begin{array}{l}\text { Sucre State: } \\
\text { Valdez Municipality }\end{array}$ & $\begin{array}{ll}\text { - } & \text { Ecoclimatic Region: } \\
& \text { Humid tropics low (B3) } \\
\text { - } & \text { Altitude: } \leq 500 \mathrm{~m} \\
\text { - } & \text { AP: }>1.800 \mathrm{~mm} \\
\text { - } & \text { AAT: } 18-24^{\circ} \mathrm{C}\end{array}$ & $\begin{array}{l}\text { Areas with very frequent } \\
\text { or almost permanent } \\
\text { flooding caused by tidal } \\
\text { flows and river flooding }\end{array}$ & $\begin{array}{l}\text { Small banana plantation } \\
\text { areas commonly } \\
\text { associated in indigenous } \\
\text { conucos }\end{array}$ \\
\hline \multirow{4}{*}{ Central } & $\begin{array}{l}\text { Miranda State: } \\
\text { Municipalities: Carrizal } \\
\text { and Los Salias }\end{array}$ & $\begin{array}{ll}\text { - } & \text { Ecoclimatic Region: } \\
& \text { Subhumid premontane } \\
\text { tropics }(\mathrm{C} 1) \\
\text { - } & \text { Altitude: } 1.300 \mathrm{~m} \\
\text { - } & \text { AP: } 1.300-1.500 \mathrm{~mm} \\
\text { - } & \text { AAT: } 18-24^{\circ} \mathrm{C}\end{array}$ & $\begin{array}{l}\text { Areas of soils with } \\
\text { moderate drainage and } \\
\text { moderate natural fertility }\end{array}$ & $\begin{array}{l}\text { Highly productive } \\
\text { systems and potential } \\
\text { importance for } \\
\text { diversification of } \\
\text { Musaceae with } \\
\text { vegetables and } \\
\text { other fruits }\end{array}$ \\
\hline & $\begin{array}{l}\text { Miranda State: } \\
\text { Municipality Acevedo }\end{array}$ & $\begin{array}{ll}\text { - } & \text { Ecoclimatic Region: } \\
\text { Humid tropics low }(\mathrm{B} 1) \\
\text { - } & \text { AP: }>1.800 \mathrm{~mm} \\
\text { - } & \text { AAT: }>24^{\circ} \mathrm{C}\end{array}$ & $\begin{array}{l}\text { Areas with a predominance } \\
\text { of flat topography, with } \\
\text { moderate to good natural } \\
\text { fertility soils }\end{array}$ & $\begin{array}{l}\text { Intensive banana } \\
\text { production systems }\end{array}$ \\
\hline & $\begin{array}{l}\text { Miranda State: } \\
\text { Brion and Buroz } \\
\text { Municipalities } \\
\text { Aragua State: } \\
\text { Libertador } \\
\text { Municipality }\end{array}$ & $\begin{array}{ll}\text { - } & \text { Ecoclimatic Region: } \\
\text { Subhumid tropics low } \\
\text { (A1) } \\
\text { - } & \text { Altitude: }<200 \mathrm{~m} \\
\text { - } & \text { AP: } 700-1.800 \mathrm{~mm} \\
\text { - } & \text { AAT: }>24^{\circ} \mathrm{C}\end{array}$ & $\begin{array}{l}\text { It includes flat areas, with } \\
\text { soils of good to moderate } \\
\text { drainage, moderate natural } \\
\text { fertility and risk of } \\
\text { physical deterioration of } \\
\text { the soil due to compaction } \\
\text { and surface sealing }\end{array}$ & $\begin{array}{l}\text { Large-scale production } \\
\text { systems, the Buroz } \\
\text { municipality is the most } \\
\text { important in banana } \\
\text { production in } \\
\text { Miranda state }\end{array}$ \\
\hline & Vargas State & $\begin{array}{ll}\text { - } & \text { Ecoclimatic Region: } \\
& \text { Subhumid tropics } \\
& \text { low (A4) } \\
\text { - } & \text { Altitude: }<500 \mathrm{~m} \\
\text { - } & \text { AP: } 700-1.200 \mathrm{~mm} \\
\text { - } & \text { AAT: }>24{ }^{\circ} \mathrm{C}\end{array}$ & $\begin{array}{l}\text { Flat areas, with low to very } \\
\text { low natural soil fertility } \\
\text { and excessive } \\
\text { tendency drainage }\end{array}$ & $\begin{array}{l}\text { Medium scale } \\
\text { production systems }\end{array}$ \\
\hline
\end{tabular}


Table 3. Cont.

\begin{tabular}{|c|c|c|c|c|}
\hline Zone & Location & Climatic Characteristics * & Edaphic Characteristics & $\begin{array}{l}\text { Predominant } \\
\text { Production Systems }\end{array}$ \\
\hline \multirow{3}{*}{ Western } & $\begin{array}{l}\text { Trujillo State: } \\
\text { Bolivar and La Ceiba } \\
\text { Municipalities } \\
\text { Zulia State: } \\
\text { La Cañada de } \\
\text { Urdaneta, Colón, } \\
\text { Francisco Javier Pulgar } \\
\text { and Miranda } \\
\text { Municipalities }\end{array}$ & $\begin{array}{ll}\text { - } & \text { Ecoclimatic Region: } \\
& \text { Subhumid tropics low } \\
& \text { (A1) } \\
\text { - } & \text { Altitude: }<200 \mathrm{~m} \\
\text { - } & \text { AP: } 1.200 \mathrm{~mm} \\
\text { - } & \text { AAT: }>24^{\circ} \mathrm{C}\end{array}$ & $\begin{array}{l}\text { Flat areas, with soils of } \\
\text { good to moderate drainage, } \\
\text { high fertility, and risk of } \\
\text { physical deterioration of } \\
\text { the soil due to compacted } \\
\text { layers (plow floor), surface } \\
\text { sealing, crusting and } \\
\text { water erosion }\end{array}$ & $\begin{array}{l}\text { Commercial plantations } \\
\text { of Musaceae on the } \\
\text { alluvial plains } \\
\text { Maracaibo Lake }\end{array}$ \\
\hline & $\begin{array}{l}\text { Trujillo State: } \\
\text { Sucre and Candelaria } \\
\text { Municipalities } \\
\text { Merida State: } \\
\text { Alberto Adriani } \\
\text { and Sucre } \\
\text { Municipalities } \\
\text { Táchira State: } \\
\text { Ayacucho Municipality }\end{array}$ & $\begin{array}{ll}\text { - } & \text { Ecoclimatic Region: } \\
\text { Humid premontane } \\
\text { tropics (D1) } \\
\text { - } \quad \text { Altitude: } 400-600 \mathrm{~m} \\
\text { - } \quad \text { AP: } 1.600-1.800 \mathrm{~mm} \\
\text { - } & \text { AAT: } 18-24^{\circ} \mathrm{C}\end{array}$ & $\begin{array}{l}\text { Its main limitations are } \\
\text { water erosion and acidity } \\
\text { of soils, which coexist with } \\
\text { some areas of } \\
\text { better fertility }\end{array}$ & $\begin{array}{l}\text { Commercial and } \\
\text { semi-commercial } \\
\text { plantations of Musaceae }\end{array}$ \\
\hline & $\begin{array}{l}\text { Zulia State: } \\
\text { Guajira Municipality }\end{array}$ & 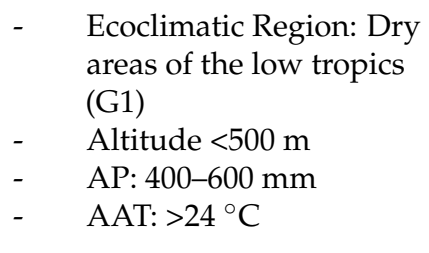 & $\begin{array}{l}\text { Saline soils and high risk of } \\
\text { physical deterioration due } \\
\text { to surface sealing. The } \\
\text { irrigation and water } \\
\text { quality are determining } \\
\text { factors for agricultural use }\end{array}$ & $\begin{array}{l}\text { Subsistence and } \\
\text { semi-commercial } \\
\text { small-scale agriculture }\end{array}$ \\
\hline \multirow{2}{*}{$\begin{array}{l}\text { South- } \\
\text { western }\end{array}$} & $\begin{array}{l}\text { Apure State: } \\
\text { Paéz Municipality } \\
\text { Barinas state: } \\
\text { Obispos Municipality }\end{array}$ & $\begin{array}{ll}\text { - } & \text { Ecoclimatic Region: } \\
& \text { Subhumid tropics low } \\
& \text { (A5) } \\
\text { - } & \text { Altitude: }<500 \mathrm{~m} \\
\text { - } & \text { AP: } 1000-1.100 \mathrm{~mm} \\
\text { - } & \text { AAT: }>24^{\circ} \mathrm{C}\end{array}$ & $\begin{array}{l}\text { Flat areas with good to } \\
\text { moderate drainage soils } \\
\text { and moderate fertility }\end{array}$ & $\begin{array}{l}\text { The largest commercial } \\
\text { systems of Musaceae in } \\
\text { southern Maracaibo Lake } \\
\text { and Zulia State }\end{array}$ \\
\hline & $\begin{array}{l}\text { Barinas state: } \\
\text { Pedraza and Barinas } \\
\text { Municipalities }\end{array}$ & $\begin{array}{ll}\text { - } & \text { Ecoclimatic Region: } \\
& \text { Humid tropics low (B2) } \\
\text { - } & \text { Altitude: }<500 \mathrm{~m} \\
\text { - } & \text { AP: }>1.800 \mathrm{~mm} \\
\text { - } & \text { AAT: }>24^{\circ} \mathrm{C}\end{array}$ & $\begin{array}{l}\text { Areas with a varied } \\
\text { topography and soils with } \\
\text { low to very low } \\
\text { natural fertility }\end{array}$ & $\begin{array}{l}\text { Systems of } \\
\text { semi-commercial } \\
\text { production of Musaceae } \\
\text { from } 100 \text { to } 200 \text { ha }\end{array}$ \\
\hline
\end{tabular}

* Ecoclimatic Region according to INIA [81]; AP: Annual precipitation; AAT: Average annual temperature.

\subsection{High-Risk Areas}

Cavendish banana large-scale farms located in the municipalities Colón, Francisco Javier Pulgar and La Cañada de Urdaneta in Zulia State are at high potential risk (Figure 4b) because: (i) they include large plantations (500-1900 ha) of genetic clones highly susceptible to Foc TR4 like Cavendish (Pineo Gigante, Williams); (ii) they present edaphoclimatic characteristics (precipitation greater than $1200 \mathrm{~mm}$ and mean diurnal temperature range of $24-34{ }^{\circ} \mathrm{C}$ ) suitable for the appearance and establishment of the pathogen; (iii) theyimplement intensive production systems, which requires the continuous movement of employees between plantations; and (iv) a single source of water for irrigation can favor the spread of the fungus within and across plantations on soil particles and irrigation water. Additionally, the physical proximity with Colombia puts these western municipalities of Venezuela at risk because the border with Venezuela is approximately $120 \mathrm{~km}$ from the Foc infected area in Colombia and at a distance of around $300 \mathrm{~km}$ from the banana zones at the south of the Maracaibo Lake. 


\subsection{Moderate to High-Risk Areas}

Medium-scale Cavendish banana production systems (200-500 ha) can be considered areas of moderate to high vulnerability to Foc TR4. These plantations are mainly located in La Guajira in Zulia State, some areas in the Alberto Adriani and Sucre municipalities at the State of Mérida and Barinas municipality at Barinas state (Figure 4d). As indicated for large-scale production systems, the pathogen can enter and disseminate due to the movement of employees, materials, tools and irrigation water within and between farms.

\subsection{Moderate to Low-Risk Areas}

Production systems based on mixed banana varieties supplying local markets (100-200 ha) are considered a moderate to low risk to the Foc TR4. These areas are located mainly in the central and eastern parts of the country, some areas of Trujillo State, Aragua and Miranda state (Figure 4c), Sucre state (Figure 4e) and south of Maracaibo Lake (Figure 4b). This risk category also includes production systems based on intercropping.

\section{Climatic Suitability for Fusarium oxysporum f. sp. cubense TR4 Occurrence in Venezuela}

Maximum Entropy (MaxEnt) models are widely used to model potential distribution of organisms covering diverse aims including finding correlation of species occurrences, mapping their current geographic distributions, or predicting new times and places [85]. MaxEnt estimates a target probability distribution by finding the probability distribution with maximum entropy (i.e., that is most spread out, or closest to uniform), subject to a set of constraints that represent our incomplete information about the target distribution [85]. MaxEnt integrates species' occurrences with background data (i.e., randomly selected points) from spatial environmental gradients in the study area and generates the probability of species' presence [85]. It identifies areas that have conditions most like species' current known occurrences and ranks them from ' 0 ' (unsuitable or most dissimilar) to ' 1 ' (most suitable or most similar).

In this perspective, MaxEnt model v. 3.4 .3 [85] was used to estimate the potential for the establishment of Foc TR4 in Venezuela. Presence-only data was obtained from the current known global distribution of Foc TR4 obtained from the following sources: (i) The CABI Crop Protection Compendium (CABI/EPPO, 2015) [25], (ii) the ProMusa project website (https:/ / www.promusa.org/Tropical+race+4+-+TR4\#Distribution) [27] and (iii) from reviewing the specialized literature. We only selected references that contained geographical information about the presence of the pathogen. To reduce spatial autocorrelation, presence records were submitted to spatial filtering, delimiting a minimum distance of $1 \mathrm{~km}$ between each locality data [86] using the spThin package in $R$ and repeated four times. For pseudo-absences generation, a weight for presences and absences to simulate a prevalence of 0.1 was used. Climate data was obtained from Chelsa Climatology [87] that includes monthly mean temperature and precipitation patterns for the 1979-2013 period. Nineteen bioclimatic variables were derived from monthly temperature and precipitation values and are intended to approximate climate dimensions meaningful to biological species and represent annual characteristics (e.g., Temperature Annual Range), seasonality (e.g., Precipitation Seasonality) and extreme environmental factors [88]. Multicollinearity was addressed by the variance inflation factor (VIF) using a threshold of 10 [89]. The climate suitability was estimated based on bioclimatic variables representing annual trends. Nine non-correlated bioclimatic variables were selected based on VIF for model fitting. These variables included: mean diurnal range [mean monthly (maximum temperature-minimum temperature)] (bio2), isothermality (bio3), mean temperature of the wettest quarter (bio8), mean temperature of the driest quarter (bio9), mean temperature of the warmest quarter (bio10), precipitation of the coldest month (bio13), precipitation seasonality (bio15), precipitation of the warmest quarter (bio18) and precipitation of the coldest quarter (bio19). The contribution of these bioclimatic variables assessed by their variance importance based on AUC indicated that the potential geographic distribution of 
Foc TR4 in Venezuela is mostly influenced by the mean diurnal temperature range (bio2) and precipitation, but particularly during extreme cold (bio13) and warm (bio18) periods of the season.

The MaxEnt predictions were generated with the sdm package in R [90] using a fivefold cross-validation procedure. Model performance was evaluated using several widely established threshold-dependent statistics: specificity, sensitivity, and the true skill statistics (TSS), as well as threshold independent statistics: the area under the curve (AUC) of the Receiver Operating Characteristic (ROC) plot and Cohen's Kappa [91].

Results indicated that the performance of the model was considered high. The AUC was estimated in $0.93 \pm 0.0236$, the sensitivity in $0.94 \pm 0.052$, the specificity $0.87 \pm 0.044$, and the TSS and the Cohen's kappa were estimated in $0.81 \pm 0.052$ and $0.55 \pm 0.085$, respectively. The map with the continuous suitability scores for the Foc TR4 in Venezuela drawn from the MaxEnt model is presented in Figure 5a and the Figure 5b show four-level categorized suitability. Except for some areas in the central and eastern part of the Bolivar state, the northern part of the Amazonas state and the Andes Mountains in the west, for which the potential for establishment is estimated negligible, the rest of the country could have climatic conditions that would allow the establishment of Foc TR4, with the central part of the country being classified with low suitability between 0.1 to 0.3 ; interestingly, all regions in northern states are classified as moderately suitable between 0.3 to 0.6 and most of the banana producing areas in the states of Zulia, Trujillo, Miranda and Sure have climatic conditions that are estimated as highly suitable $>0.6$ for the establishment of Foc TR4 (Figure 5).

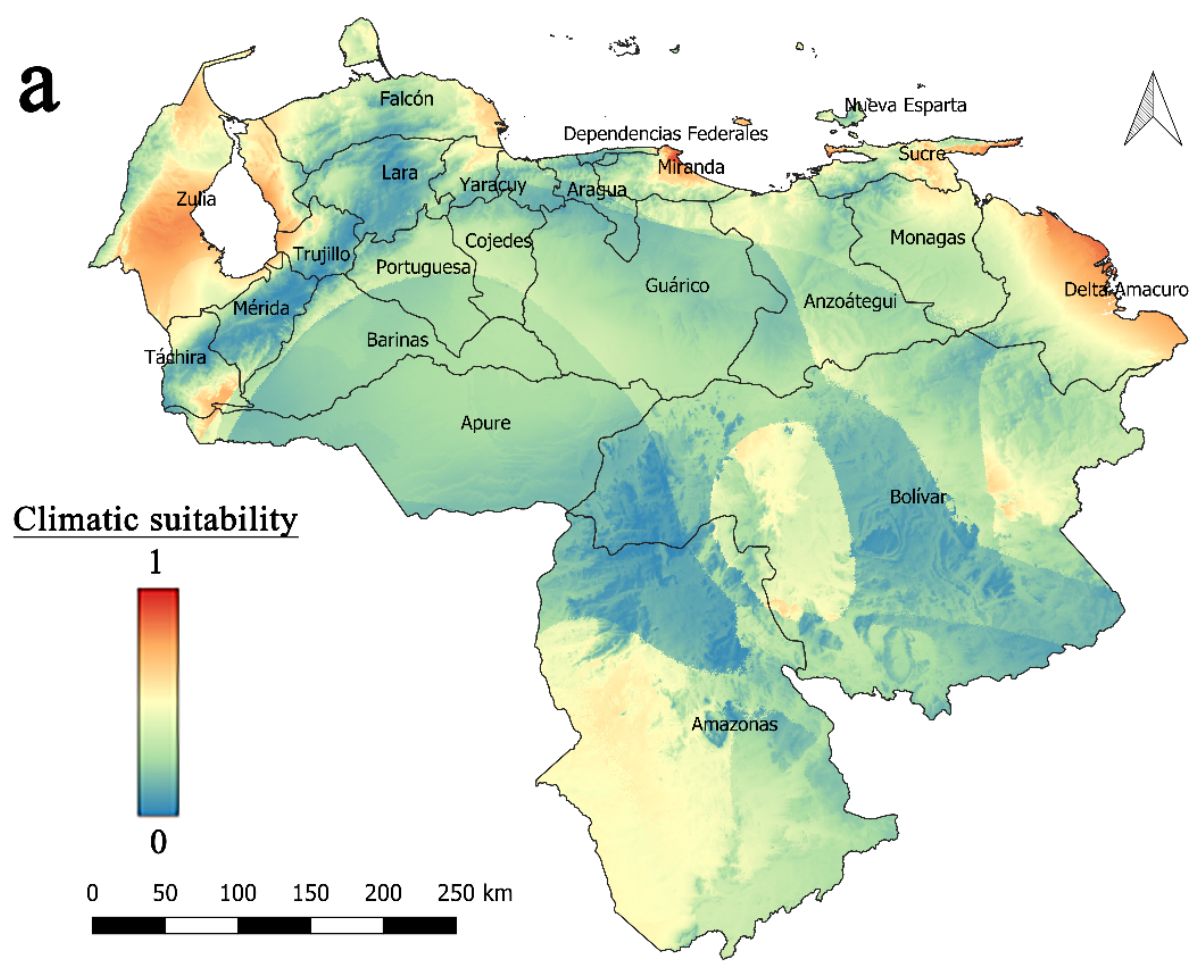

Figure 5. Cont. 


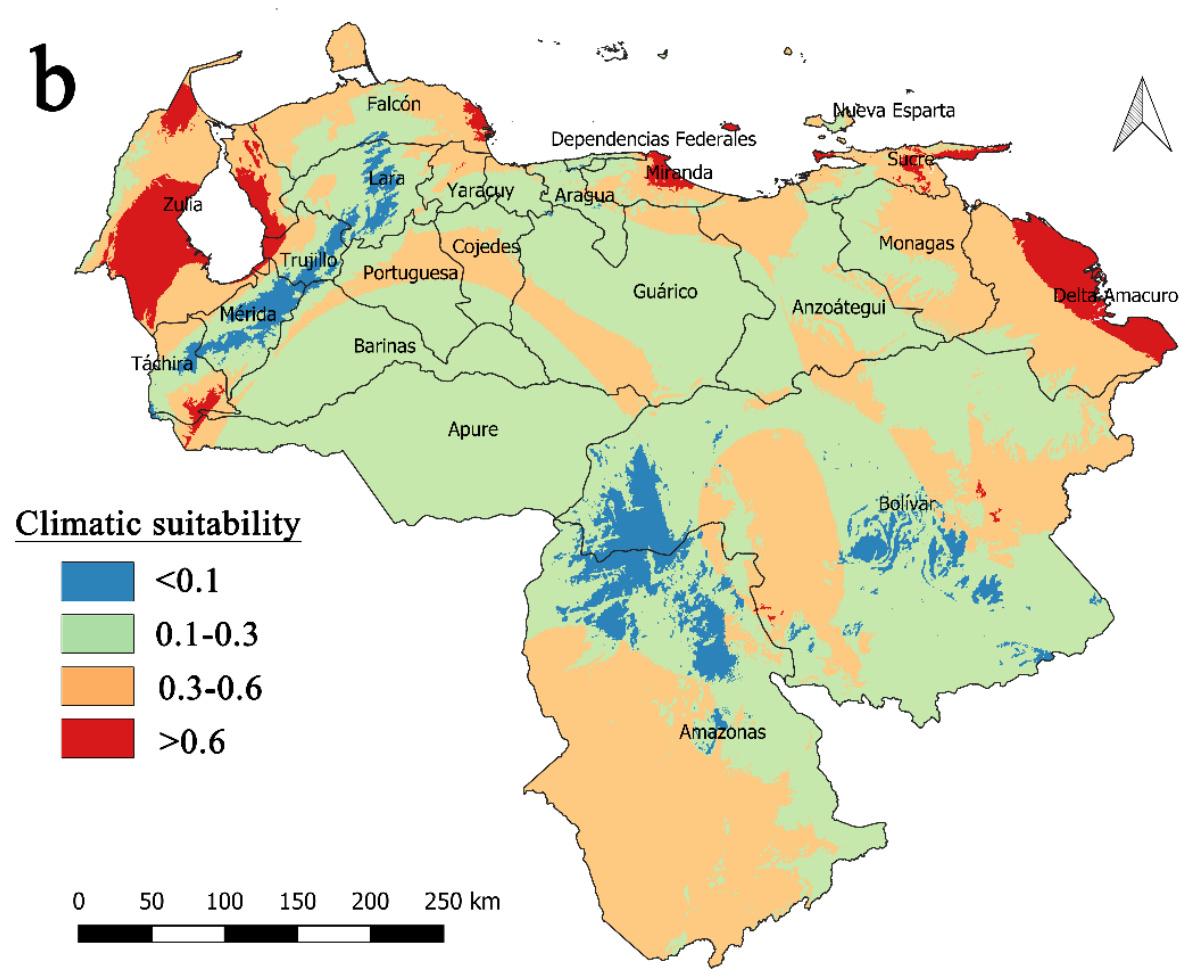

Figure 5. Estimated climatic suitability maps for Fusarium oxysporum f. sp. cubense TR4 according to a Maximum entropy model. (a) Climatic suitability index 0 to 1; (b) Climatic suitability index categorized in four levels: unsuitable $(<0.1)$, low $(0.1-0.3)$, moderately $(0.3-0.6)$ and highly suitable $(>0.6)$.

\section{Integrated Approach to the Prevention of Fusarium oxysporum f. sp. cubense TR4 Occurrence in Venezuela}

The recent occurrence of Foc TR4 in commercial farms in the Colombian Guajira region in July 2019, has increased the risk to Foc TR4 on the Venezuelan banana-producing areas due to proximity to the outbreak. According to Dita et al. [22,92], these border areas will be necessary to implement state policies, with the exclusion being the main priority to prevent the movement of propagation material, establish quarantine sectors and promote awareness campaigns to inform producers on the serious threat that Foc TR4 represents for the Venezuelan banana sector.

In Venezuela, intensive banana systems located in the western region (Zulia state) are more at risk to Foc TR4 as extremely strict biosafety protocols are required. Due to the absence of efficient control measures once the plant is infected in the field, the best way to protect the crop is to prevent the introduction of the pathogen from affected areas and the use of resistant banana cultivars to Foc TR4 such as Giant Cavendish tissue-culture variants [93].

Small-scale Cavendish banana production systems located in most of Venezuela's territory are characterized by using sprouts as a propagation system instead of tissue crops. Farmers also tend to share planting and transport tools, and neglect the sanitary practices at the time of planting, which considerably increases the chance of introducing the fungus from affected crops to pathogen-free plantations. On the contrary, production systems based on mixed banana cultivars, as well as mixed crops, subsistence and indigenous farming systems in areas of the southwest and east of Venezuela are considered less vulnerable areas to the economic damage that the occurrence of Foc TR4 pathogen attack, due to the diversity of banana cultivars and the possibility to replace banana by other crops.

In this context, Table 4 lists the main activities that could be implemented to prevent the entry and spread of this pathogen, and more specifically of the highly virulent Foc TR4 in Venezuela. In summary, results indicate that the best approach to fight against the 
threat that Foc TR4 assume includes prevention approaches, the use of resistant/tolerant cultivars, as well as the implementation of good phytosanitary practices at planting time. However, these measures are very expensive and require highly trained personnel to identify the pathogen and control it. Unfortunately, in areas still free of this highly virulent race, such as the case of Venezuela, there are few specialists working on this disease. Consequently, it is important to build technical capabilities in growers, services providers and national plant protection agents to identify Foc symptoms in the field, and to implement identification methodologies based mainly on the use of modern molecular diagnostic tools to unequivocally identify this highly virulent race of the pathogen.

Table 4. Activities aimed at preventing the entry and spread of Fusarium oxysporum f. sp. cubense (Foc) TR4 in the banana production systems of Venezuela. Adapted from FAO [79].

\section{Type of Action Description of the Activity}

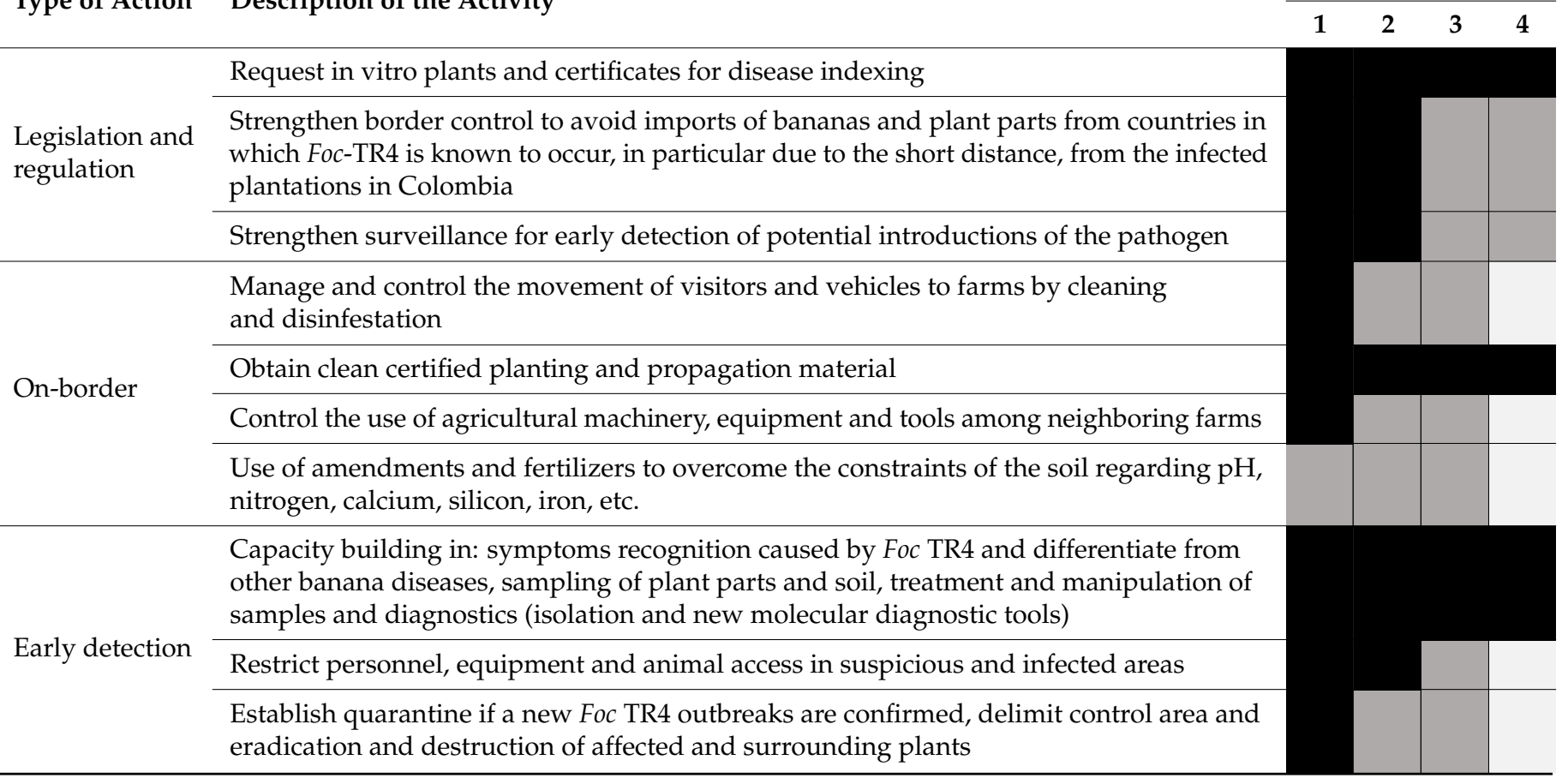

1 = Large-scale Cavendish monoculture; 2 = small-scale Cavendish monoculture; 3 = small and medium scale mixed banana; 4 = small-scale mixed crops, subsistence and indigenous agriculture.
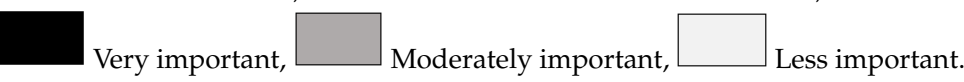

\section{Conclusions}

The progress made in FW of banana research in tropical producing regions is still insufficient to adequately define the mechanisms of prevention and control of this disease $[10,22]$. Despite several studies finding correlations between incidence and virulence of FW with different climate variables, soil properties and management practices, there is not a comprehensive understanding of the overall impact of these properties and their interactions. Previous research carried out by scientific and academic institutions, together with the producer associations, shows that no product (biological or chemical) is capable of effectively eradicating this disease once it has been detected and established in a field, although some studies indicate a reduction of FW using biological control agents (BCAs). Consequently, the implementation of eradication or exclusion protocols in affected areas has been suggested as one of the main management strategies in order to prevent the spread of the pathogen, especially of the highly virulent tropical race 4 (TR4) of Foc to areas free of the pathogen or specifically of the TR4 strain. Nevertheless, the agro-environmental factors compiled in this perspective may provide an overview of the influence of environmental and agroecological variables on the susceptibility of banana plants to FW. With this infor- 
mation, agricultural practices in banana plantations could be improved, soil management practices promoted and new farm locations proposed in suitable areas, which will lead to more opportunities to control the coexistence between Foc and banana production in Venezuela as well as in other banana producing countries.

Author Contributions: B.O.O., J.A.N.-C. and B.B.L. conceptualization and writing of manuscript; B.O.O. and J.A.N.-C. data analyses, B.O.O., J.A.N.-C. prepared Figures; J.C.R., D.L., J.A.G. review and edited the manuscript. All authors have read and agreed to the published version of the manuscript.

Funding: This work was partially funded by projects "Technological innovations for the management and improvement of the quality and health of banana soils in Latin America and the Caribbean" financed by FONTAGRO and coordinated by Bioversity International (before INIBAP). BOO was recipient of a PhD fellowship from The Iberoamerican Association of Postgraduate Universities (Spanish: Asociación Universitaria Iberoamericana de Postgrado), the international mobility fellowship from the Ibero-American General Secretary of the Carolina Foundation in Costa Rica (2019) and Action KA107 of Erasmus+ Program from Agrifood Campus of International Excellence (ceiA3) (2020).

Institutional Review Board Statement: Not applicable.

Informed Consent Statement: Not applicable.

Acknowledgments: The authors wish to thank the researchers Gustavo Martínez from the National Institute of Agricultural Research of Venezuela and Cesar Acevedo from University of Talca (Chile) for providing access to information on Fusarium in Bananas and their valuable comments. Also, to José Riera for the graphic design and Miguel López Beltrán for cartographic support.

Conflicts of Interest: The authors declare no conflict of interest.

\section{References}

1. FAO. Banana Statistical Compendium Year 2019. Available online: http://www.fao.org/3/cb0466en/cb0466en.pdf (accessed on 16 March 2020).

2. Olivares, B.O.; Araya-Alman, M.; Acevedo-Opazo, C.; Rey, J.C.; Cañete-Salinas, P.; Kurina, F.G.; Balzarini, M.; Lobo, D.; NavasCortés, J.A.; Landa, B.B.; et al. Relationship between soil properties and banana productivity in the two main cultivation areas in venezuela. J. Soil Sci. Plant 2020, 20, 2512-2524. [CrossRef]

3. Ploetz, R.C.; Nishijima, G.A.; Rohrbach, W.T.; Kg Ohr, H.D. Compendium of Tropical Fruit Diseases; The American Phytopathological Society: Washington, DC, USA, 1994; pp. 7-28.

4. Kema, G.H.J.; Drenth, A.; Dita, M.; Jansen, K.; Vellema, S.; Stoorvogel, J.J. Editorial: Fusarium wilt of banana, a recurring threat to global banana production. Front. Plant Sci 2021, 11, 628888. [CrossRef]

5. Shabani, F.; Kumar, L.; Esmaeili, A. Future distributions of Fusarium oxysporum f. spp. in European, Middle Eastern and North African agricultural regions under climate change. Agric. Ecosyst. Environ. 2014, 197, 96-105. [CrossRef]

6. Stover, R.H. Fusarium Wilt (Panama Disease) of Banana and Other Musa Species; Phytopathology Paper 4; Commonwealth Mycological Institute: Kew Surrey, UK, 1962; pp. 17-29.

7. Ploetz, R.C. Panama-Disease-Return of the first banana menace. Int. J. Pest Manag. 1994, 40, 326-336. [CrossRef]

8. Ploetz, R.C.; Pegg, K. Fusarium Wilt in Diseases of Banana, Abaca and Enset; CABI Publishing: Wallingford, UK, 2000 ; pp. 143-159.

9. Pérez-Vicente, L. Marchitamiento por Fusarium (Mal de Panamá) en bananos: Una revisión actualizada del conocimiento presente sobre su agente causal. Fitosanidad 2004, 8, 27-38.

10. Pocasangre, L.E.; Ploetz, R.C.; Molina, A.B.; Vicente, L.P. Raising awareness of the threat of fusarium wilt tropical race 4 in latin america and the caribbean. Acta Hortic. 2011, 897, 331-337. [CrossRef]

11. Ploetz, R.C. Fusarium wilt of banana. Phytopathology 2015, 105, 1512-1521. [CrossRef] [PubMed]

12. Ploetz, R.C. Management of fusarium wilt of banana: A review with special reference to tropical race 4. Crop Prot. 2015, 73, 7-15. [CrossRef]

13. Ghag, S.B.; Shekhawat, U.K.S.; Ganapathi, T.R. Fusarium wilt of banana: Biology, epidemiology and management. Int. J. Pest Manag. 2015, 61, 250-263. [CrossRef]

14. Dita, M.; Barquero, M.; Heck, D.; Mizubuti, E.S.G.; Staver, C.P. Fusarium wilt of banana: Current knowledge on epidemiology and research needs toward sustainable disease management. Front. Plant Sci. 2018, 9, 1468. [CrossRef] [PubMed]

15. Bubici, G.; Kaushal, M.; Prigigallo, M.I.; Cabanas, C.G.L.; Mercado-Blanco, J. Biological control agents against fusarium wilt of banana. Front. Microbiol. 2019, 10, 616. [CrossRef] [PubMed]

16. Nelson, P.E. History of fusarium systematics. Phytopathology 1991, 81, 1045-1048.

17. Davis, R. Fusarium wilt (Panama disease) of banana. Pest. Adv. Leaflet 2005, 42, 1-8.

18. Bentley, S.; Pegg, K.G.; Moore, N.Y.; Davis, R.D.; Buddenhagen, I.W. Genetic variation among vegetative compatibility groups of Fusarium oxysporum f. sp. cubense analyzed by DNA fingerprinting. Phytopathology 1998, 88, 1283-1293. [CrossRef] 
19. Ploetz, R.C. Fusarium wilt of banana is caused by several pathogens referred to as Fusarium oxysporum f. sp cubense. Phytopathology 2006, 96, 653-656. [CrossRef] [PubMed]

20. Maryani, N.; Lombard, L.; Poerba, Y.S.; Subandiyah, S.; Crous, P.W.; Kema, G.H.J. Phylogeny and genetic diversity of the banana Fusarium wilt pathogen Fusarium oxysporum f. sp. cubense in the Indonesian centre of origin. Stud. Mycol. 2009, 92, 155-194. [CrossRef] [PubMed]

21. Buddenhagen, I. Understanding Strain Diversity in Fusarium oxysporum f. sp cubense and History of Introduction of 'Tropical Race 4' to Better Manage Banana Production. Acta Hortic. 2009, 828, 193-204. [CrossRef]

22. Dita, M.; Perez-Vicente, L.; Guzman, M.; Urias, C.; Staver, C. Fusarium tropical race 4 and it threat to food security and the banana industry in Latin America and the Caribbean. Phytopathology 2017, 107, 8.

23. Molina, A.B.; Fabregar, E.; Sinohin, V.G.; Yi, G.; Viljoen, A. Recent Occurrence of Fusarium oxysporum f. sp cubense Tropical Race 4 in Asia. Acta Hortic. 2009, 828, 109-115. [CrossRef]

24. Garcia-Bastidas, F.; Ordonez, N.; Konkol, J.; Al-Qasim, M.; Naser, Z.; Abdelwali, M.; Salem, N.; Waalwijk, C.; Ploetz, R.C.; Kema, G.H.J. First report of Fusarium oxysporum f. sp cubense tropical race 4 associated with panama disease of banana outside southeast asia. Plant Dis. 2014, 98, 694. [CrossRef]

25. CABI/EPPO. Fusarium oxysporum f. sp. cubense. Distribution Maps of Plant Diseases, Map 31, 7th ed.; CABI: Wallingford, UK, 2015.

26. EPPO. PQR Database. European and Mediterranean Plant Protection Organization: Paris, France, 2014. Available online: https://gd.eppo.int/taxon/FUSACB/distribution (accessed on 16 March 2021).

27. PROMUSA. Available online: http:/ / www.promusa.org/Tropical+race+4+-+TR4\#Distribution (accessed on 16 March 2021).

28. FONTAGRO. Available online: https:/ / www.fontagro.org/new/proyectos/fusarium-R4 (accessed on 16 March 2021).

29. Waite, B.H.; Dunlap, V.C. Preliminary host range studies with Fusarium oxysporum f. cubense. Plant Dis. Rep. 1953, 37, 79-80.

30. Olivares, B.O. Tropical rainfall conditions in rainfed agriculture in Carabobo, Venezuela. La Granca 2018, 27, 86-102. [CrossRef]

31. Martínez, G.E.; Rey-Brina, J.C.; Rodríguez, D.; Jiménez, C.; Rodríguez, Y.; Rumbos, R.; Pargas-Pichardo, R.; Martínez, E. Análisis de la situación fitopatológica actual de las musáceas comestibles en Venezuela. Agr. Trop. 2020, 70, 1-20. [CrossRef]

32. Bosman, M. Role of the Environment on the Incidence of Panama Disease in Bananas; Wageningen University: Wageningen, The Netherlands, 2016; pp. 12-68.

33. Robinson, J.C.; International, C.A.B. Bananas and Plantains; CAB International: Wallingford, CT, USA, 1996 ; p. 312.

34. Pérez, L.; Batlle, A.; Fonseca, J. Fusarium oxysporum f. sp. cubense en Cuba: Biología de las poblaciones, reacción de los clones híbridos de la FHIA y biocontrol. In Proceedings of the Taller Internacional Manejo Convencional y Alternativo de la Sigatoka Negra, Nematodos y Otras Plagas Asociadas al Cultivo de Musáceas, MUSALAC/INIBAP, Guayaquil, Ecuador, 11-13 August 2003.

35. Groenewald, S.; van den Berg, N.; Marasas, W.F.O.; Viljoen, A. Biological, physiological and pathogenic variation in a genetically homogenous population of Fusarium oxysporum f. sp. cubense. Australas. Plant Pathol. 2006, 35, 401-409. [CrossRef]

36. Brake, V.M.; Pegg, K.G.; Irwin, J.A.G.; Chaseling, J. The influence of temperature, inoculum level and trace of Fusarium-oxysporum f. sp. cubense on the disease reaction of banana cv. cavendish. Aust. J. Agric. Res. 1995, 46, 673-685. [CrossRef]

37. Ploetz, R.C. Population biology of Fusarium oxysporum f. sp. cubense. In Fusarium Wilt of Banana; Ploetz, R.C., Ed.; APS Press: St. Paul, MN, USA, 1990; Volume 1, pp. 63-76.

38. Pérez-Vicente, L.; Porras, Á. Impacto potencial del cambio climático sobre las plagas de bananos y plátanos en Cuba. Fitosanidad 2015, 19, 201-211.

39. Olivares, B.; Cortez, A.; Lobo, D.; Parra, R.; Rey, J.; Rodriguez, M. Evaluation of agricultural vulnerability to drought weather in different locations of Venezuela. Rev. Fac. Agron. 2017, 34, 103-129.

40. Nansamba, M.; Sibiya, J.; Tumuhimbise, R.; Karamura, D.; Kubiriba, J.; Karamura, E. Breeding banana (Musa spp.) for drought tolerance: A review. Plant Breed. 2020, 139, 685-696. [CrossRef]

41. Lahav, E.; Israeli, Y. Mineral Deficiencies of Banana. In Diseases of Banana, Abacá and Enset; Jones, D., Ed.; CABI Publishing: Wallingford, Oxon, UK, 2000; pp. 339-350.

42. Aguilar, E.A.; Turner, D.W.; Sivasithamparam, K. Fusarium oxysporum f. sp cubense inoculation and hypoxia alter peroxidase and phenylalanine ammonia lyase activities in nodal roots of banana cultivars (Musa sp.) differing in their susceptibility to Fusarium wilt. Aust. J. Bot. 2000, 48, 589-596. [CrossRef]

43. Summerell, B.A.; Leslie, J.F.; Liew, E.C.Y.; Laurence, M.H.; Bullock, S.; Petrovic, T.; Burgess, L.W. Fusarium species associated with plants in Australia. Fungal Divers. 2011, 46, 1-27. [CrossRef]

44. Rishbeth, J. Fusarium wilt of bananas in jamaica: II. Some aspects of host-parasite relationships. Ann. Bot. 1957, 21, 215-245. [CrossRef]

45. Bronick, C.J.; Lal, R. Soil structure and management: A review. Geoderma 2005, 124, 3-22. [CrossRef]

46. Li, Z.; Deng, Z.; Chen, S.; Yang, H.; Zheng, Y.; Dai, L.; Zhang, F.; Wang, S.; Hu, S. Contrasting physical and biochemical properties of orchard soils suppressive and conducive to Fusarium wilt of banana. Soil Use Manag. 2018, 34, 154-162. [CrossRef]

47. Domínguez, J.; Negrin, M.A.; Rodriguez, C.M. Aggregate water-stability, particle-size and soil solution properties in conducive and suppressive soils to Fusarium wilt of banana from Canary Islands (Spain). Soil Biol. Biochem. 2001, 33, 449-455. [CrossRef]

48. Domínguez-Hernandez, J.; Negrin, M.A.; Rodriguez, C.M. Soil potassium indices and clay-sized particles affecting banana-wilt expression caused by soil fungus in banana plantation development on transported volcanic soils. Commun. Soil Sci. Plant Anal. 2008, 39, 397-412. [CrossRef] 
49. Deltour, P.; Franca, S.C.; Pereira, O.L.; Cardoso, I.; De Neve, S.; Debode, J.; Hofte, M. Disease suppressiveness to Fusarium wilt of banana in an agroforestry system: Influence of soil characteristics and plant community. Agric. Ecosyst. Environ. 2017, 239, 173-181. [CrossRef]

50. Pegg, K.G.; Moore, N.Y.; Bentley, S. Fusarium wilt of banana in Australia: A review. Aust. J. Agric. Res. 1996, 47, 637-650. [CrossRef]

51. Pittaway, P.A.; Nasir, N.; Pegg, K.G. Soil receptivity and host-pathogen dynamics in soils naturally infested with Fusarium oxysporum f. sp. cubense the cause of Panama disease in bananas. Aust. J. Agric. Res. 1999, 50, 623-628. [CrossRef]

52. Segura, R.A.; Serrano, E.; Pocasangre, L.; Acuna, O.; Bertsch, F.; Stoorvogel, J.J.; Sandoval, J.A. Chemical and microbiological interactions between soils and roots in commercial banana plantations (Musa AAA, cv. Cavendish). Sci. Hortic. 2015, 197, 66-71. [CrossRef]

53. Chuang, T.Y. Soil suppressive of banana Fusarium wilt in Taiwan. Plant Prot. Bull. 1991, 33, 133-141.

54. Peng, H.X.; Sivasithamparam, K.; Turner, D.W. Chlamydospore germination and Fusarium wilt of banana plantlets in suppressive and conducive soils are affected by physical and chemical factors. Soil Biol. Biochem. 1999, 31, 1363-1374. [CrossRef]

55. Segura Mena, R.; Stoorvogel, J.J.; Garcia-Bastidas, F.; Salacinas-Niez, M.; Sandoval, J.A.; Kema, G. Soil management as an effective strategy for crop disease management: The case of panama disease in banana. In Proceedings of the Book of Abstract of the Wageningen Soil Conference: Soil Science in a Changing World, Wageningen, The Netherlands, 23-27 August 2015 ; p. 48.

56. Gutiérrez Jerez, F.; Borges-Pérez, A.; Trujillo Jacinto del Castillo, I. Estudio sobre el mal de panamá en las islas canarias. I. Características físicas y químicas de los suelos y su relación con la aparición de la enfermedad. Fruits 1983, 38, 677-682.

57. Huber, D.; Römheld, V.; Weinmann, M. Relationship between nutrition, plant diseases and pests. In Mineral. Nutrition of Higher Plants, 3rd ed.; Marschner, P., Ed.; Academy Press: Stuttgart, Germany, 2012; pp. 283-298. [CrossRef]

58. Borges, A.F.; Bravo, J.J.; Perez, J.F.; Lopez, I. Enhanced resistance of banana plants (Dwarf Cavendish) to Fusarium oxysporum f. sp cubense by controlled Zn nutrition under field conditions. Banan. Newsl. 1991, 14, 24-26.

59. Borges-Pérez, A.; Angulo Rodríguez, D.; Gutiérrez Jerez, F.; Trujillo Jacinto del Castillo, I. Estudio sobre el Mal de Panamá en las Islas Canarias. II. Influencia de los desequilibrios nutritivos P-Zn y K-Mg del suelo, en la alteración de los mecanismos de resistencia de la platanera (Cavendish enana) al Mal de Panamá. Fruits 1983, 38, 755-758.

60. Rasiah, V.; Armour, J.D.; Moody, P.W.; Pattison, A.B.; Lindsay, S.; Florentine, S. Characterizing and improving the deteriorating trends in soil physical quality under banana. Aust. J. Soil Res. 2009, 47, 574-584. [CrossRef]

61. Pattison, A.B.; Wright, C.L.; Kukulies, T.L.; Molina, A.B. Ground cover management alters development of Fusarium wilt symptoms in Ducasse bananas. Australas. Plant Pathol. 2014, 43, 465-476. [CrossRef]

62. Huang, X.; Wen, T.; Zhang, J.; Meng, L.; Zhu, T.; Cai, Z. Toxic organic acids produced in biological soil disinfestation mainly caused the suppression of Fusarium oxysporum f. sp cubense. Biocontrol 2015, 60, 113-124. [CrossRef]

63. Zhang, H.; Mallik, A.; Zeng, R.S. Control of panama disease of banana by rotating and intercropping with chinese chive (Allium tuberosum Rottler): Role of plant volatiles. J. Chem. Ecol. 2013, 39, 243-252. [CrossRef] [PubMed]

64. Nasira, N.; Pittaway, P.A.; Pegg, K.G. Effect of organic amendments and solarization on Fusarium wilt in susceptible banana plantlets, transplanted into naturally infested soil. Aust. J. Agric. Res. 2003, 54, 251-257. [CrossRef]

65. Shen, Z.; Penton, C.R.; Lv, N.; Xue, C.; Yuan, X.; Ruan, Y.; Li, R.; Shen, Q. Banana fusarium wilt disease incidence is influenced by shifts of soil microbial communities under different monoculture spans. Microb. Ecol. 2018, 75, 739-750. [CrossRef]

66. Shen, Z.Z.; Ruan, Y.Z.; Xue, C.; Zhong, S.T.; Li, R.; Shen, Q.R. Soils naturally suppressive to banana fusarium wilt disease harbor unique bacterial communities. Plant Soil 2015, 393, 21-33. [CrossRef]

67. Deng, X.; Li, Q.F.; Hou, X.W.; Wu, C.Y. Soil microbial functional diversity from different infection grades of banana fusarium wilt (Fusarium oxysporum f. sp cubense). Appl. Mech. Mater. 2013, 295, 2274-2280. [CrossRef]

68. Pirttila, A.M. Commentary: Agroforestry leads to shifts within the gammaproteobacterial microbiome of banana plants cultivated in Central America. Front. Microbiol. 2016, 7, 656. [CrossRef]

69. Koberl, M.; Dita, M.; Martinuz, A.; Staver, C.; Berg, G. Agroforestry leads to shifts within the gammaproteobacterial microbiome of banana plants cultivated in Central America. Front. Microbiol. 2015, 6, 91. [CrossRef]

70. Koberl, M.; Dita, M.; Martinuz, A.; Staver, C.; Berg, G. Members of Gammaproteobacteria as indicator species of healthy banana plants on Fusarium wilt-infested fields in Central America. Sci. Rep. 2017, 7, 9. [CrossRef] [PubMed]

71. Shen, Z.; Wang, B.; Lv, N.; Sun, Y.; Jiang, X.; Li, R.; Ruan, Y.; Shen, Q. Effect of the combination of bio-organic fertiliser with Bacillus amyloliquefaciens NJN-6 on the control of banana Fusarium wilt disease, crop production and banana rhizosphere culturable microflora. Biocontrol Sci. Technol. 2015, 25, 716-731. [CrossRef]

72. Dinesh, B.M.; Ravichandra, N.G.; Reddy, B.M.R.; Somasekhara, Y.M. Interactions between Radopholus similis and Fusarium oxysporum f. sp. cubense causing wilt Complex on Banana. Int. J. Adv. Res. 2014, 2, 976-985.

73. Ritzinger, C.H.S.P.; Fancelli, M. Integrated management of nematodes in the banana tree culture. Rev. Bras. Frutic. 2006, 28, 331-338. [CrossRef]

74. Almeida, N.O.; Teixeira, R.A.; Carneiro, F.A.; de Oliveira, C.M.; Ribeiro, V.A.; Lobo Junior, M.; da Rocha, M.R. Occurrence and correlations of nematodes, Fusarium oxysporum and edaphic factors on banana plantations. J. Phytopathol. 2018, 166, $265-272$. [CrossRef]

75. Duyck, P.-F.; Pavoine, S.; Tixier, P.; Chabrier, C.; Queneherve, P. Host range as an axis of niche partitioning in the plant-feeding nematode community of banana agroecosystems. Soil Biol. Biochem. 2009, 41, 1139-1145. [CrossRef] 
76. Zhong, S.; He, Y.D.; Zeng, H.C.; Mo, Y.W.; Jin, Z.Q. Effects of banana wilt disease on soil nematode community structure and diversity. Afr. J. Biotechnol. 2011, 10, 12759-12767. [CrossRef]

77. Li, W.M.; Dita, M.; Rouard, M.; Wu, W.; Roux, N.; Xie, J.H.; Ge, X.J. Deep RNA-seq analysis reveals key responding aspects of wild banana relative resistance to Fusarium oxysporum $\mathrm{f}$. sp. cubense tropical race 4. Funct. Integr. Genom. 2020, 20, 551-562. [CrossRef] [PubMed]

78. Hennessy, C.; Walduck, G.; Daly, A.; Padovan, A. Weed hosts of Fusarium oxysporum f. sp cubense tropical race 4 in northern Australia. Australas. Plant Pathol. 2005, 34, 115-117. [CrossRef]

79. Pérez-Vicente, L.; Dita, M.A.; Martínez de la Parte, E. Technical Manual: Prevention and Diagnostic of Fusarium Wilt (Panama Disease) of Banana Caused by Fusarium oxysporum f. sp. cubense Tropical Race 4 (TR4). Prepared for the FAO/CARDI Regional Workshop on the Diagnosis of Fusarium Wilt (Panama Disease) Caused by Fusarium oxysporum f. sp. cubense Tropical Race 4: Mitigating the Threat and Preventing it Spread in the Caribbean; University of West Indies: St. Augustine, Trinidad and Tobago, 2014.

80. Waman, A.A.; Bohra, P.; Sathyanarayana, B.N.; Chandrashekar, S.C.; Rani, R.T. Are bananas (Musa spp.) really safe from their aesthetic relatives? Screening potential alternative hosts of Fusarium oxysporum f. sp cubense. J. Hortic. Sci. Biotechnol. 2013, 88, 559-562. [CrossRef]

81. Stover, R.H. Fusarium wilt (panama disease) of bananas-Current status and control strategies. Acta Hortic. 1990, $275,707-712$. [CrossRef]

82. INIA (Instituto Nacional de Investigaciones Agrícolas, VE). Aproximación Agroecológica para el Nuevo Modelo de Producción Agrícola en Venezuela; Editorial del Instituto Nacional de Investigaciones Agrícolas: Maracay, Venezuela, 2016; pp. 12-90.

83. Wood-Sichra, U.; Joglekar, A.B.; You, L. Spatial Production Allocation Model (SPAM) 2005; Technical Documentation. Harvest Choice Working Paper; Harvest Choice: St. Paul, MN, USA, 2016.

84. You, L.; Wood, S.; Wood-Sichra, U.; Wu, W. Generating global crop distribution maps: From census to grid. Agric. Syst. 2014, 127, 53-60. [CrossRef]

85. Phillips, S.J.; Anderson, P.R.; Schapire, R.E. Maximum entropy modeling of species geographic distributions. Ecol. Model. 2006, 190, 231-259. [CrossRef]

86. Boria, R.A.; Olson, L.E.; Goodman, S.M.; Anderson, R.P. Spatial filtering to reduce sampling bias can improve performance of ecological niche models. Ecol. Model. 2014, 275, 73-77. [CrossRef]

87. Karger, D.N.; Conrad, O.; Böhner, J.; Kawohl, T.; Kreft, H.; Soria-Auza, R.W.; Zimmermann, N.E.; Linder, H.P.; Kessler, M. Climatologies at high resolution for the earth's land surface areas. Sci. Data 2017, 4, 170122. [CrossRef]

88. Hijmans, R.J.; Cameron, S.E.; Parra, J.L.; Jones, P.G.; Jarvis, A. Very high-resolution interpolated climate surfaces for global land areas. Int. J. Climatol. 2005, 25, 1965-1978. [CrossRef]

89. Chatterjee, S.; Hadi, A.S. Regression Analysis by Example; John Wiley and Sons: Hoboken, NJ, USA, 2006 ; pp. 80-127.

90. Naimi, B.; Araujo, M.B. Sdm: A reproducible and extensible R platform for species distribution modelling. Ecography 2016, 39, 368-375. [CrossRef]

91. Allouche, O.; Tsoar, A.; Kadmon, R. Assessing the accuracy of species distribution models: Prevalence, kappa and the true skill statistic (TSS). J. Appl. Ecol. 2006, 43, 1223-1232. [CrossRef]

92. Dita, M.; Echegoyén Ramos, P.E.; Pérez Vicente, L.F. Plan de Contingencia Ante un Brote de la Raza 4 Tropical de Fusarium oxysporum f. sp. Cubense, en un País de la Región Del OIRSA; OIRSA Editorial: San Salvador, El Salvador, 2013; p. 155.

93. Huang, B.; Xu, L.; Molina, A.B., Jr. Preliminary Evaluation of IMTP-III Varieties and Local Cultivars against Fusarium Wilt Disease in South China; International Plant Genetic Resources Institute (IPGRI): Rome, Italy, 2005; pp. 187-192. 